\title{
Woody debris production and deposition during floods at extreme rainfall period 2012-2013 in Yabe and Tsuwano River Basin, Japan
}

\author{
Muhammad Islamy Rusyda ${ }^{1}$, Sinya Ikematsu ${ }^{2}$ and Haruyuki Hashimoto ${ }^{3}$ \\ Civil Engineering Department, Faculty of Engineering, Muhammadiyah University of Mataram, Indonesia \\ Urban and Environmental Engineering Department, Faculty of Engineering, Kyushu University, Japan \\ Former Professor of Civil Engineering Department, Faculty of Engineering, Kyushu University, Japan
}

Received: 2020-02-24 Accepted: 2020-07-19

Keywords: woody debris, accumulation, wood pieces, river, flood

Correspondent email: lamyrusyda@yahoo.co.id

\begin{abstract}
The behavior of woody debris has become a critical issue in river dynamics. It is still not widely understood, particularly during a flood event. Field investigations were performed to investigate the characteristics of woody debris production and deposition during the 2012 and 2013 floods in Yabe and Tsuwano River Basin, Japan. Ground-level photos, aerial photos, and direct measurements were used to measure the length and diameter of woody debris, characteristics of obstacles (length. width, diameter, and shape). These investigations revealed that woody debris deposition was divided into two types: the rest of individual woody debris pieces on the riverside slope or floodplain and the formation of a woody debris jam at obstacles such as bridges, riparian trees, houses, and irregular topographic relief. Individual woody debris pieces at the production sites are around two times longer than those at the deposition sites. However, the variation coefficient of piece length at the production sites is smaller than that at the deposition site. Our results also show that the most extended piece in the jam and horizontal scale of the obstacle are two essential factors in jam formation. An empirical equation for predicting the apparent volume of jam at an obstacle is also proposed.
\end{abstract}

(2020 by the authors. Licensee Indonesian Journal of Geography, Indonesia.

This article is an open access article distributed under the terms and conditions of the Creative Commons

Attribution(CC BY NC) licensehttps://creativecommons.org/licenses/by-nc/4.0/.

\section{Introduction}

Debris flows and landslides are the most common natural disasters which transported a large amount of sediment and woody debris in a river due to heavy rain in mountain areas. Debris flow transported $33 \%$ of large woody debris to the alluvial channel in the North Fork of Cherry Creek basin (May \&Gresswell, 2003). Landslides delivered more than 60\% of the number of large woody debris to a river in the upper reach of little lost Man Creek, California (Benda et al., 2002) and in Cummins Creek, Oregon (Reeves et al., 2003). Debris flows and landslides are potential mechanisms for delivering woody debris from hillslope in Yabe River basin, Fukuoka Prefecture and Tsuwano River basin within the Takatsu River basin, Shimane Prefecture (Rusyda et al. 2013, 2014)

Large quantities of woody debris are mainly delivered by natural disasters to the main river and conveyed by the flood to the river downstream. On the one hand, the woody debris can be mobilized through a river as either individual pieces or as congested accumulations (Braudricket al. 1997; Abbe and Montgomery 2003). Their mobility was influenced by specific gravity, shape, the size relative to the depth and width of flow, and channel boundary conditions (Abbe \& Montgomery, 2003). On the other hand, the woody debris can be deposited in the river and on floodplain as an individual pieces or accumulation. It depends on the length of woody debris and flow condition (e.gBocchiola,et al., 2006; Schmocker\& Hager, 2011; Ruiz-Villanueva et al., 2015), the diameter of woody debris, the density of woody debris and Manning's roughness coefficient of depositional sites (RuizVillanueva et al., 2015)

The floating woody debris is likely to be deposited at a narrow reach of the channel, at the head of mid-channel bars, in shallow zones where flow expanded, and on the outside of bends when channel depth was less than buoyant depth (Braudrick et al., 1997; Braudrick\& Grant, 2001; Welber et al., 2013). The presence of obstacles in a river can provide a place for one end of a woody debris piece to rest and form a woody debris jam, such as riparian trees (Bocchiolla et al.,2006, 2008; Abbe \& Montgomery,2003), bridges (Diehl, 1997; Ruiz-Villanueva et al., 2014, Schmocker\& Hager, 2011, Curran, 2010), channel bends (Curran 2010) and boulders (Abbe \&Montgomery,2003)

Two different types of lodging mechanisms of woody debris transport associated with riparian trees were presented by Bocchiola et al. (2006), which are: bridging and leaning. Bridging occurs when two different rods are trapped, moving woody debris and formed an accumulation. Learning occurs when a single rod trapped a woody debris piece. In the case of woody debris accumulated at the bridge, Diehl (1997) 
grouped the accumulation into single-pier accumulation and span-block age. The upstream ends of some large accumulations that form across spans and on island heads have the same structural pattern as single-pier accumulation

The woody debris at the obstacle produces its accumulation or jam, jamming the river cross-sections. As a result, it causes various problems, such as the reduction in the capacity of waterway openings, backwater rise, blockage of a river (Braudrick et al., 1997; Abbe \& Montgomery, 2003; Diehl. 1997; Schmocker\& Hager, 2011; Ruiz-Villanueva et al.,2014), scour around a jam (Wallerstein, 2003; Pagliara\&Carnacina, 2010) and increases in lateral forces on bridges (Diehl 1997).

It has been argued that the production, mobility, and deposition process of woody debris conveyed by natural disasters have become important factors for investigating river dynamics in the field of geomorphology and river engineering. The processes still play a critical role in the maintenance of the river and its floodplain

Although some research has been carried out on the behavior of woody debris, there have been few empirical investigations into woody debris trapped by obstacles in river networks during a flood event (e.g., Bocchiola et al.,2006, 2008; Schmocker \& Hager, 2011; Diehl, 1997; Curran 2010; Ruiz-Villanueva et al., 2014)

Therefore, the behavior of woody debris during the flood event has emerged as a vital issue for flood disaster prevention and reduction. There are three main questions regarding the issue: (1) How much is the production of woody debris in the river basin?; (2) What is the transport process of woody debris in rivers?; and (3) What is the deposition process of woody debris in rivers and floodplain?
Similar processes have been described by Diehl (1997). They are associated with woody debris jam at bridges; the first one is woody debris source loading, distribution, and recruitment, the second one is woody debris transport, and the last one is woody debris deposition. Furthermore, issue (3) raises the following questions: (4) How much is the scale and volume of woody debris jam? and (5) How deep is the backwater rise due to woody debris jam? This study only focuses on questions (1), (3), and (4).

This study aimed to investigate the production of woody debris, the deposition process of woody debris, and the scale and volume of woody debris jam the Yabe River basin in the southern part of Fukuoka Prefecture and the Tsuwano River basin within the Takatsu River basin in the western part of Shimane Prefecture during the 2012 and 2013 flood. This study explores : (1) the length of individual woody debris pieces in production site that initiated by landslides and debris flow; (2) the length and diameter of individual wood pieces in deposition site; and (3) the characteristics of woody debris jam that formed by obstacle and without obstacles, such as the most extended pieces in the jam, horizontal scale of jam, apparent volume of jam, horizontal scale of jam, and shaded area of jam

\section{The Methods \\ Study areas}

The study areas are located in two different river basins in Japan; one is the Yabe Riverbasinin, the southern part of Fukuoka Prefecture, and the other is the Tsuwano River basin within the Takatsu River basin in the western part of Shimane Prefecture (Figure 1).

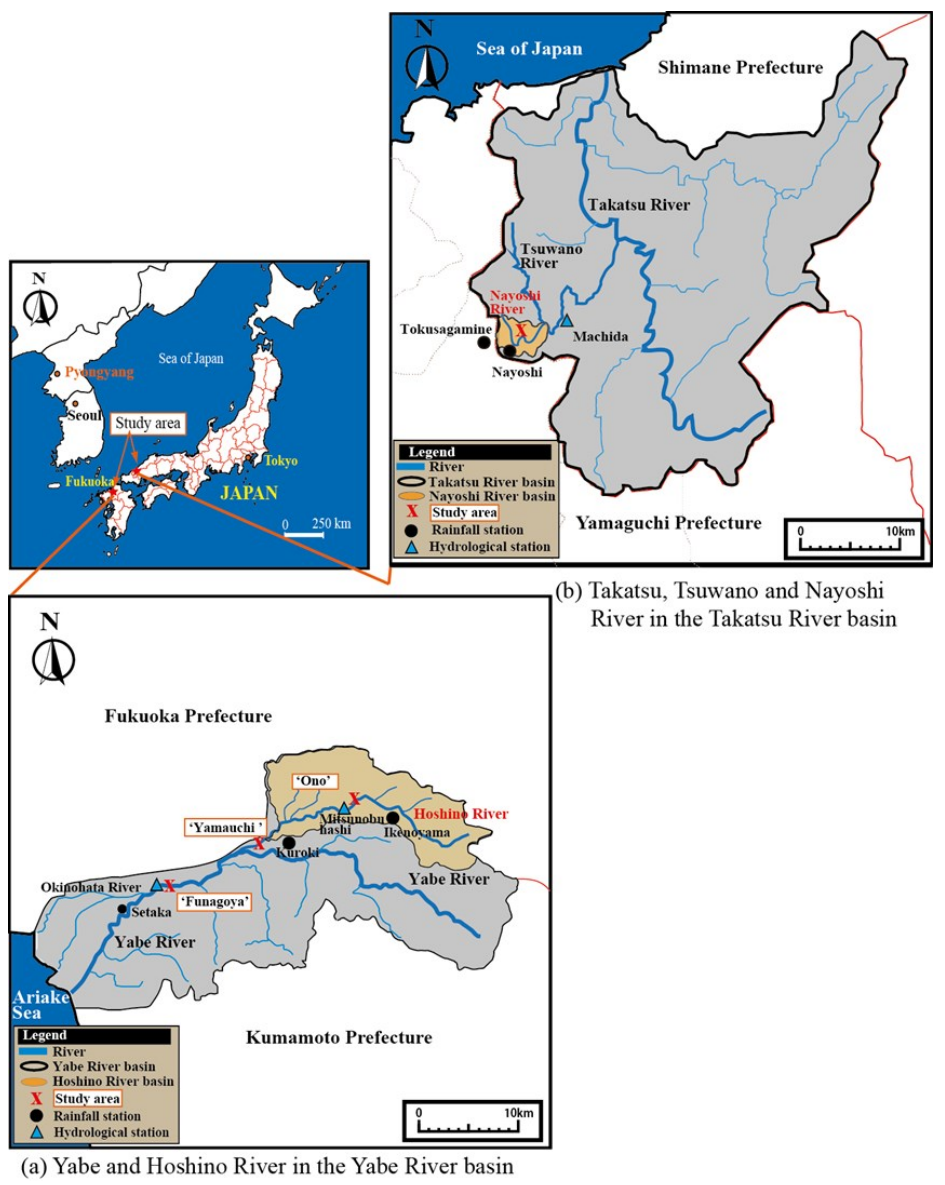

Figure 1. Locations of the study areas 


\section{The Yabe River Basin}

The Yabe River has a length of $61 \mathrm{~km}$ and a basin area of $647 \mathrm{~km}^{2}$ (Figure 1(a)). The Hoshino River joins the middle Yabe River reach. The length and the basin area of the Hoshino River is $33 \mathrm{~km}$ and $144.4 \mathrm{~km}^{2}$, respectively

Three districts in the Hoshino River reach and the other district in the middle Yabe River reach were selected as study areas; the first three districts are called 'Ono,' 'Hanzawa,' and 'Yamauchi', and the last one is 'Funagoya.'

\section{The Tsuwano River Basin}

The Tsuwano River is a tributary of the Takatsu River, which has a length of $81 \mathrm{~km}$ and a basin area of $1,090 \mathrm{~km}^{2}$ (Figure 1(b)). The Nayoshi River joins the middle TsuwanoRiver reach. The length and the basin area of the Nayoshi River is $8.7 \mathrm{~km}$ and $17.5 \mathrm{~km}^{2}$, respectively. 'Nayoshi' and 'Takamine' districts in the middle NayoshiRiverreach were selected as study areas

\section{Field surveys}

Field surveys had carried out at'Ikenoyama','Ono,' 'Hanzawa'and 'Yamauchi'districts in the middle and downstream Hoshino River reaches and at 'Funagoya' district in the middle Yabe River reach since July 2012. Furthermore, we had performed field surveys at 'Nayoshi' and 'Takamine' districts in the middleNayoshi River reach since July 2013.

We took photos of the situation of landslides and floods during the field surveys. For convenience, these were termed 'ground-level' photos. Aerial photos were also taken along the Hoshino River by Fukuoka Prefecture Government in July 2012 (oblique and vertical aerial photos) and the Nayoshi River by a few private companies of aerial survey in July 2013 (oblique aerial photos), respectively.

From the field survey, we found that the landslides and floods yielded production and deposition of a significant amount of woody debris, respectively. The situation of woody debris production and deposition were divided into two types: (1) the rest of individual woody debris pieces on the riverside slope or floodplain and (2) the formation of woody debris jams at obstacles such as bridges, riparian trees, utility poles, houses, and irregular topographic relief.

Therefore, we carried out the direct measurement of a woody debris piece's scale and a jam with a tape measure at two sites in the study areas.

First, the length and diameter of individual woody debris pieces resting in the production and deposition areas were measured. Simultaneous direct measurements of piece length and diameter were carried out every piece using a tape measure and 'ground level' photos at 'Ono' and 'Nayoshi' districts. Length of individual woody debris pieces at'Ikenoyama', 'Ono,' 'Hanzawa,' and 'Yamauchi' districts were also measured using a tape measure measurement and with aerial photos. Two different measurement methods were adopted at the districts for a comparison of the following methods: a direct measurement with a tape measure and indirect measurement with aerial photos. Figure 2 shows the aerial photos that are used to measure individual woody debris pieces.

Their statistical parameters (e.g., mean, standard deviation, variation coefficient, and probability distribution) were determined. The size characteristics of individual pieces in the production and deposition areas were compared Second, the scale and volume of a woody debris jam were measured against the scale and shaded area of an obstacle.

\section{Results and Discussion}

\section{Effect of heavy rain in Yabe River Basin}

Heavy rain occurred in the Yabe River basin on July 14, 2012. This rainfall caused several landslides and flood flow with a large amount of woody debris. 'Hanzawa'district is a location where a landslide produced woody debris. 'Ono' and 'Yamauchi'districts are locations where the flooding water deposited a large amount of woody debris.'Funagoya'district, on the other hand, is a location where the riparian trees on the left-hand side trapped a large amount of woody debris during the flood.

\section{Effect of heavy rain in Tsuwano River Basin}

Heavy rain occurred in the Tsuwano River basin on July 28,2013 . This rainfall triggered a large number of landslides and flood flow. Some of the landslides changed into debris flows and transported a large amount of woody debris to the upstream Nayoshi River reach. The transported woody debris caused blocking in small bridges without piers and flooding the field along the middle river reach. The flooding water deposited a large amount of woody debris on the field.
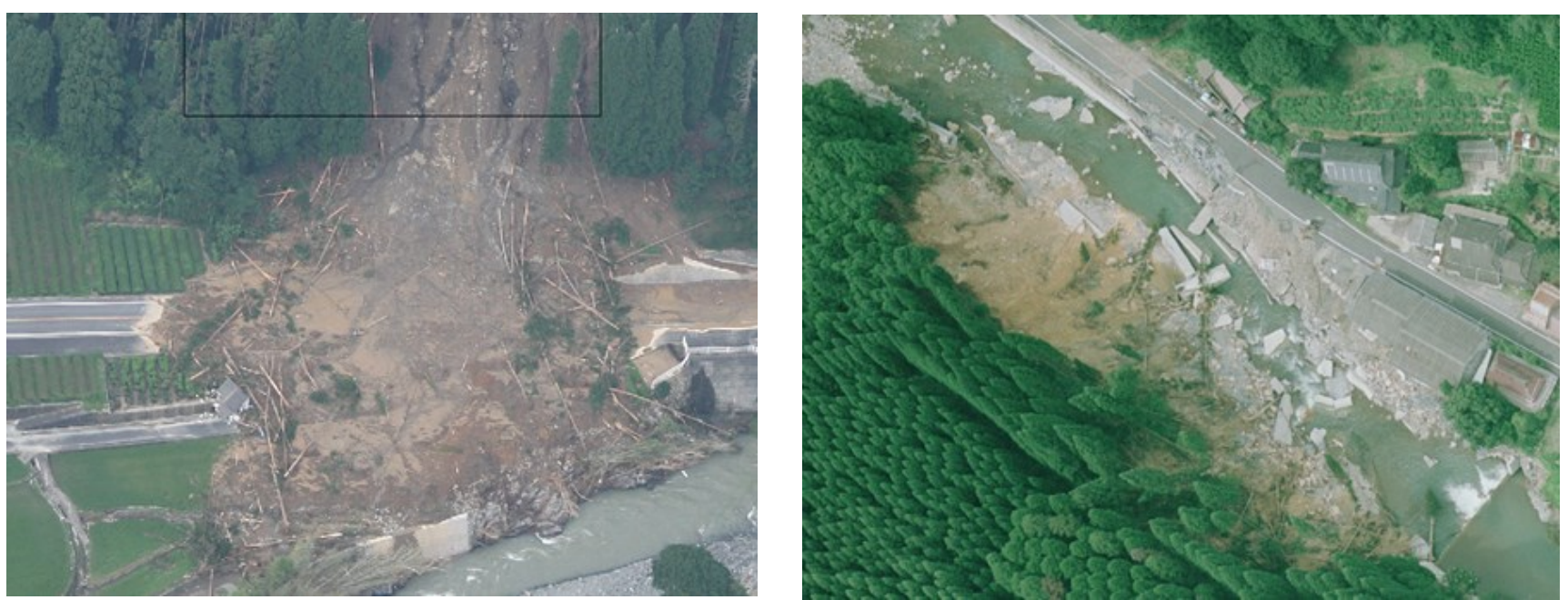

Figure 2. Aerial photos that used indirect measurement 'Hanzawa' district (the left photo) 'Ikenoyama' district (the right photo) 
Landslide and flood event in the Yabe River and Hoshino River Reach

Heavy rain hit the Yabe and Hoshino River basin from 13 to July 14, 2012. This impact resulted in 3 deaths, 113 houses destroyed, 65 houses partially damaged, and 2936 houses inundated. At the same time, landslides at 206 localities and debris flows at 14 localities occurred. The locations of typical landslides and floods in the Hoshino River basin are shown in Figure 3. This figure also includes the locations of rainfall and hydrological stations. The former is called 'Ikenoyama' rainfall station, and the latter is 'Mitsunobu-hashi' hydrological station

'Ikenoyama'rainfall station recorded the maximum hourly rainfall of $96 \mathrm{~mm}$ from 9 to 10 a.m. on July 14 and the accumulated rainfall of $613 \mathrm{~mm}$ from 13 to July 14 (Figure 4). Corresponding to this rainfall situation, the river water

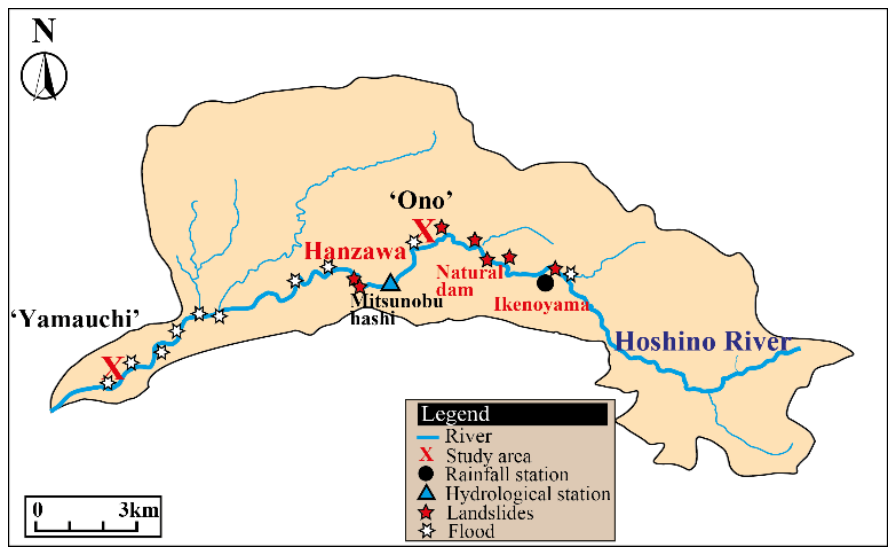

Figure 3. Locations of typical landslides and flooding along the Hoshino River
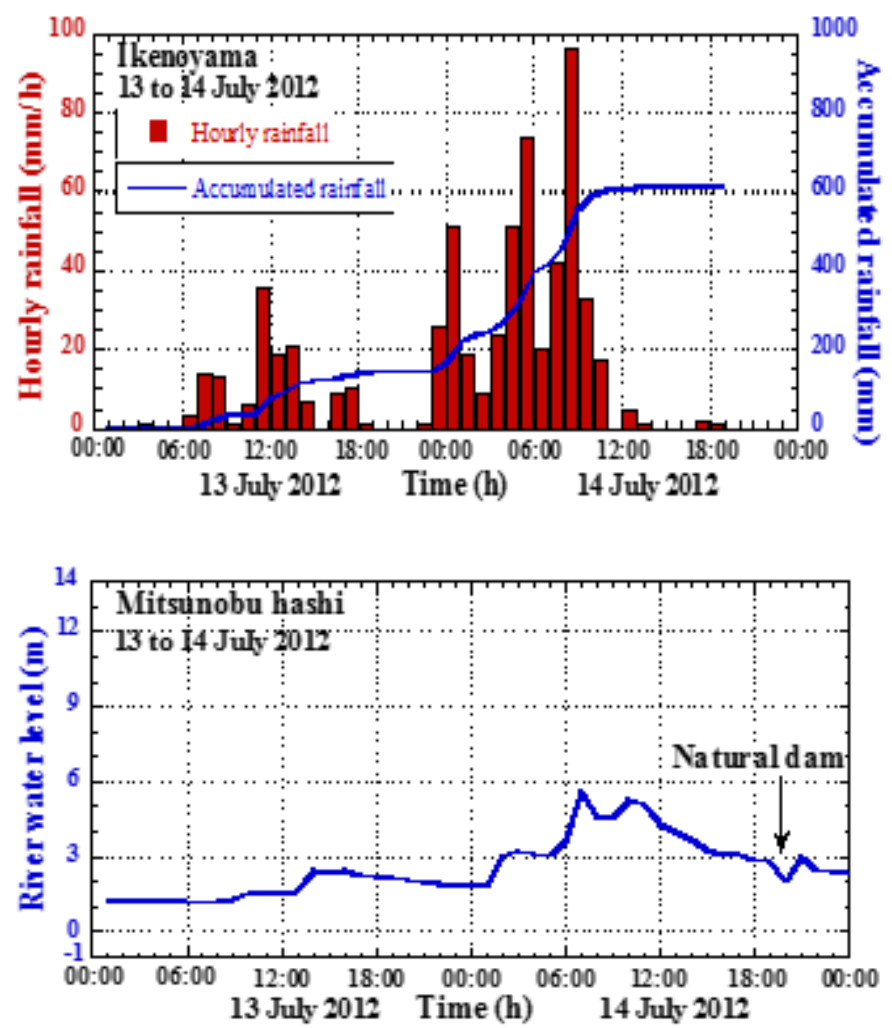

Figure 4. Measurements of rainfallat'Ikenoyama' and river water level at 'Mitsunobu-hashi.' level at 'Mitsunobuhashi' increased gradually from 1 a.m. and then reached a peak at 7 a.m. on14 July (Figure 4). These rainfall and river flow situations caused landslides on the slopes (Figure 5) and flooding on the roads and fields along the Hoshino River. The landslides along with the river, brought woody debris and sediment into the river flood flow and their flooding on plain areas. One of the landslides yielded a natural dam in the middle Hoshino River reaches at around 8 p.m. on July 14; the dam was washed away in about 30 minutes. The flooding water deposited a large amount of woody debris on the floodplain (Figure 6). Furthermore, the flood washed away Nagase bridge at 'Ono' district and Nagano bridge at 'Nagano' district.

The locations of typical floods in the middle and downstream Yabe River reaches are shown in Figure 7. This figure also includes the locations of rainfall and hydrological stations. The formers are 'Kuroki,' and 'Setaka' rainfall stations and the latter is 'Funagoya'hydrological station

'Kuroki' rainfall station in the middle Yabe River reach recorded the maximum hourly rainfall of $94 \mathrm{~mm}$ from 9 to 10 a.m. on July 14 and the accumulated rainfall of $564 \mathrm{~mm}$ from 13 to July 14 (Figure 8). Corresponding to the rainfall situation, the river water level at 'Funagoya' increased rapidly from around 2 a.m. and then reached a peak at 9 a.m. on 14 July (Figure 8). It was a record water level. Therefore, the inundation of riparian trees at the study site 'Funagoya' lasted for about 13 hours during the flood event. This river flow situation caused accumulation or jam of transported woody debris in the riparian trees. Furthermore, this situation burst the banks in the downstream Yabe River reach and in the tributary called the Okinohata River.

Landslide and flood events in Tsuwano and Nasyohi River Reach

Heavy rain hit the Tsuwano River basin on July 28, 2013. This rainfall and river flow situation caused many landslides and debris flow in the mountain area of the Nayoshi River basin (Figure 9). This impact resulted in one missing person, two houses destroyed and 111 houses inundated. At the same time, slope failures at 16 localities and debris flows at 57 localities occurred

'Nayoshi' rainfall station recorded the accumulated rainfall of $411 \mathrm{~mm}$ from 2 a.m. to 10 a.m. and the maximum

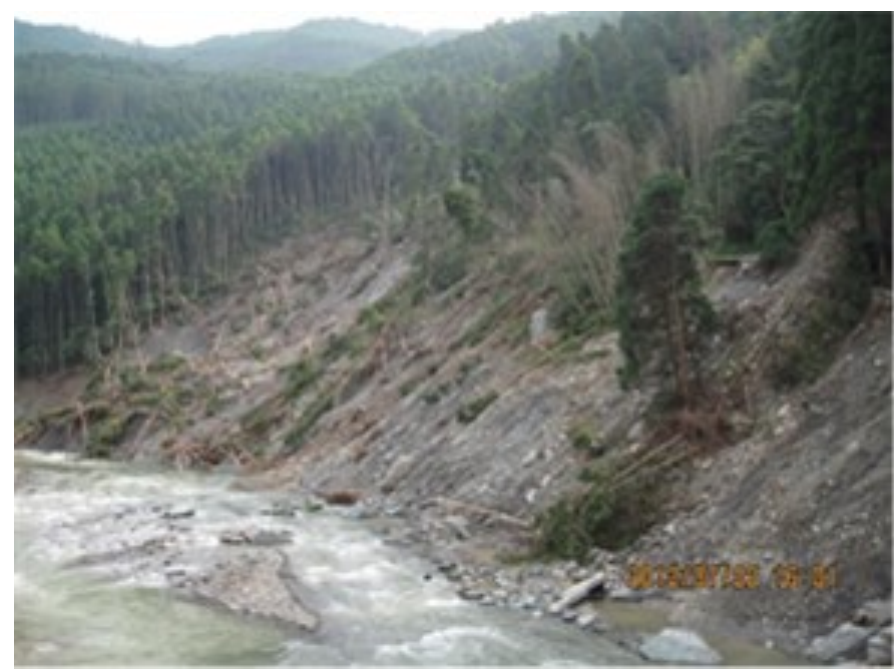

Figure 5. A landslide at 'Hanzawa'in the middle Hoshino

River reach 

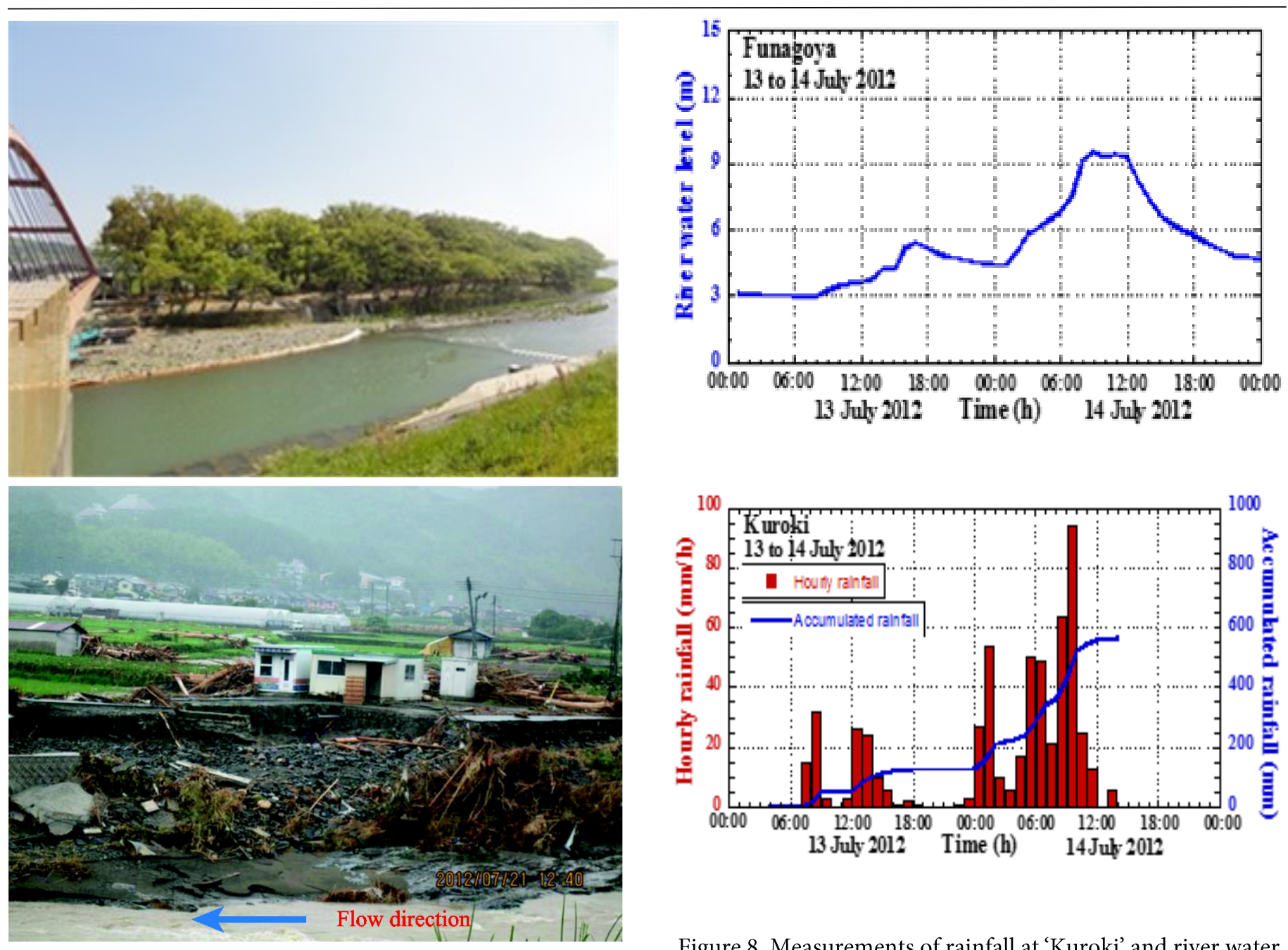

Figure 6. Woody debris deposition on the right-hand side field at 'Yamauchi' in the downstream Hoshino River reach Riparian trees standing on the left-hand side at 'Funagoya' in the middle Yabe River reach
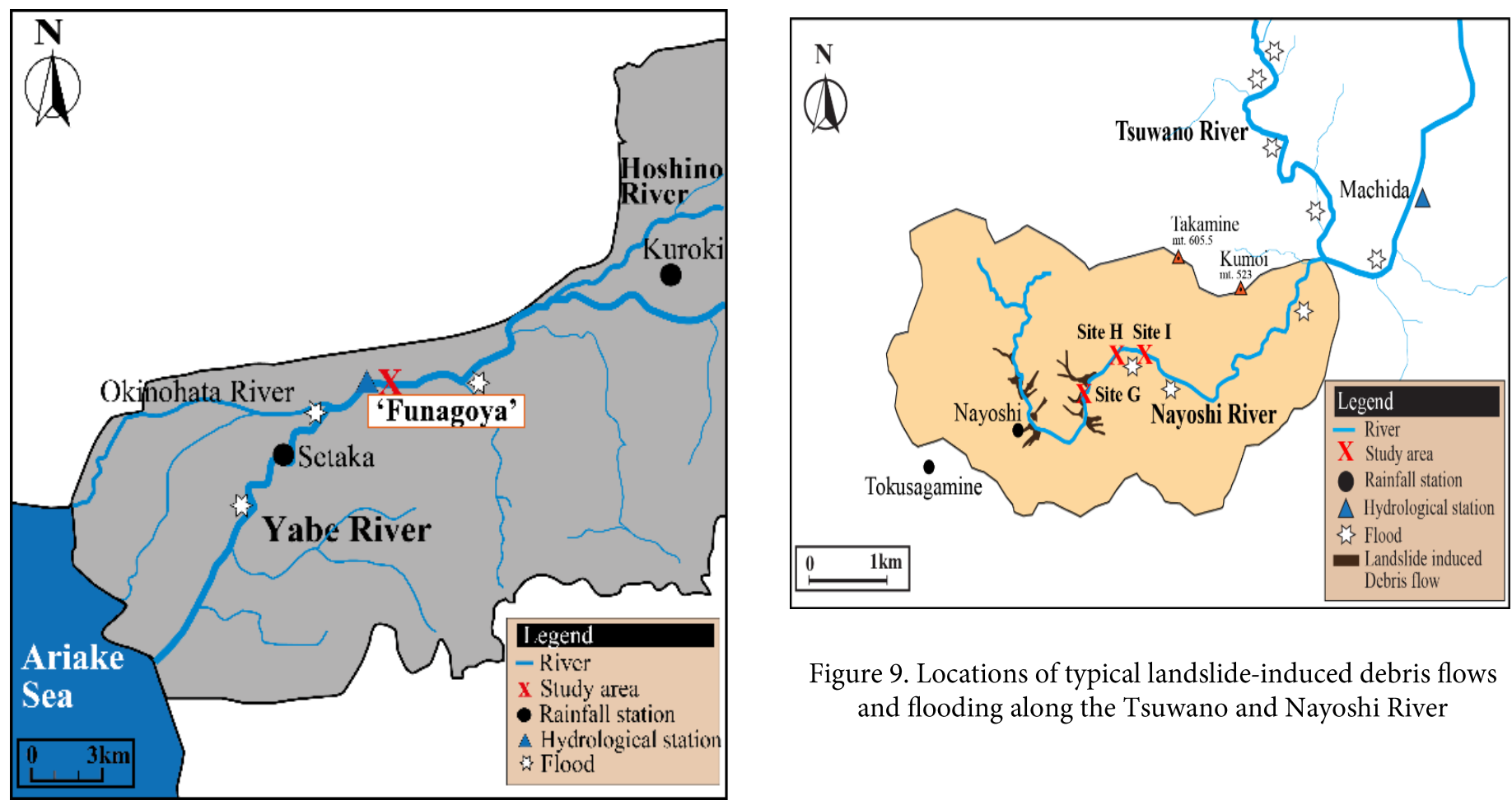

Figure 9. Locations of typical landslide-induced debris flows and flooding along the Tsuwano and Nayoshi River

Figure 7. Locations of typical flooding in the middle and downstream Yabe River reaches 
hourly rainfall of $92 \mathrm{~mm}$ from 5 a.m. to 6 a.m., although this instrument became a breakdown at around 10 a.m. 'Tokusagamine' rainfall station close to 'Nayoshi' showed the accumulated rainfall of $470 \mathrm{~mm}$ and the maximum hourly rainfall of $92 \mathrm{~mm}$ (Figure 10). Corresponding to the rainfall situation, the river water level at 'Machida' rapidly increased from around 4 a.m. and then reached a peak at 10 a.m. (Figure 10)

This rainfall and river flow situation caused many landslides and debris flow in the mountain area. We confirmed 42 landslides on the right-hand side area and 39 landslides on the left-hand side area by sight throughout the field survey. The landslides and the debris flows conveyed a significant amount of woody debris into the upstream Nayoshi River reach (Figure 11(a)). The river flood with woody debris caused by blocking in small bridges and flooding in the middle river reach (Figure 11(b)). The flooding inundated roads, fields, and houses in the Tsuwano and Nayoshi River reaches

\section{'Ikenoyama' district in the middle Hoshino River reach}

The flood caused significant erosion and produced woody debris along the left-hand riverside at 'Ikenoyama' district. Site ' $A$ ' indicates the location of the riverside erosion (Figure 12). There remained a large number of woody debris pieces on this riverside slope.

\section{'Ono' district in the middle Hoshino River reach}

'Ono'district has lower floodplains at some river sections (Figure 12). The levee protection for the floodplain was broken during the flood. There were 88 individual woody debris pieces deposited, and one woody debris jam formedon Sites 'A' and 'B'. The situation of individual woody debris pieces deposited is shown in Figure 11.
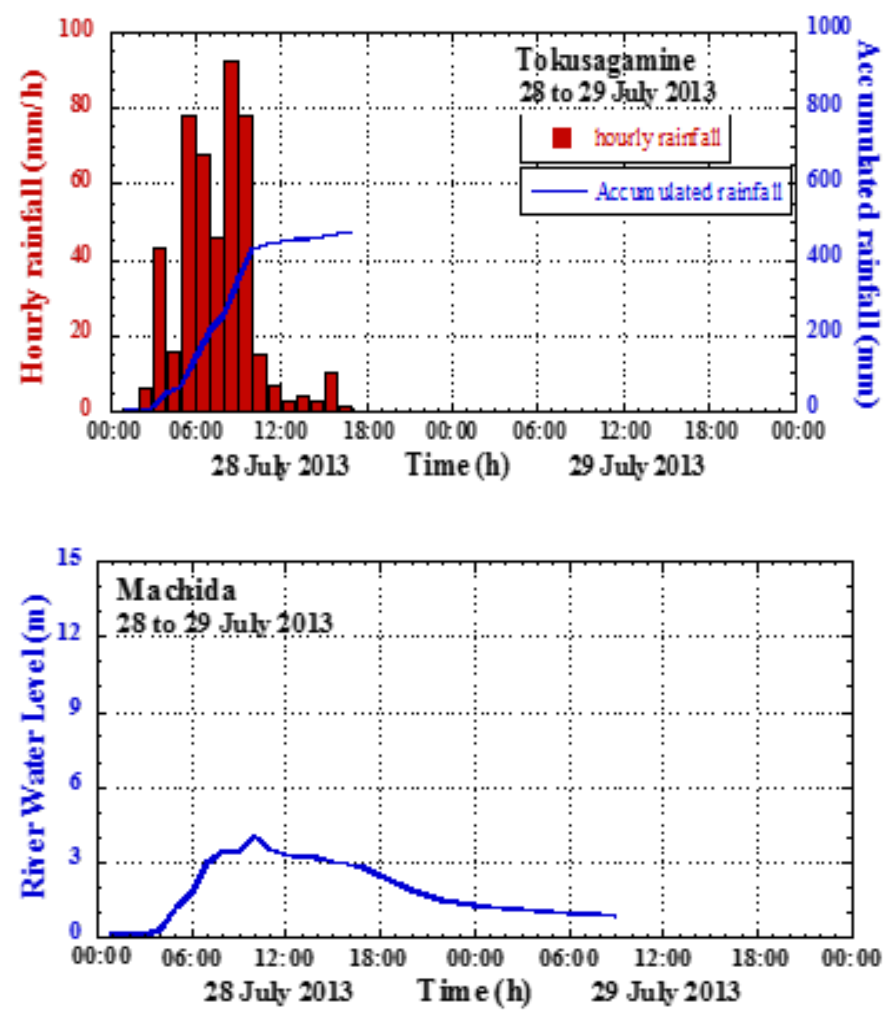

Figure 10. Measurements of rainfall at 'Nayoshi' and 'Tokusagamine' stations and river water level at 'Machida'
Hanzawa' district in the middle Hoshino River reach

The heavy rain triggered several landslides on mountain slopes and produced woody debris along the Hoshino River. Site ' $C$ ' is a typical landslide place (Figure 13). There remained a large number of woody debris pieces on this slope. These pieces rested without their movement of longdistance.

'Yamauchi'district in the downstream Hoshino River reach

Sites ' $D$ ' and ' $E$ ' in 'Yamauchi'district are lower agricultural lands (Figure 13). The flooding from the river reach occurred on Sites 'D' and 'E' of the right-hand side. We found woody debris accumulated at obstacles, such as houses and utility poles, and individual pieces deposited in these sites (Figure 15). Sixteen woody debris jams were formed, and 97 individual pieces were deposited.

\section{Funagoya' district in the middle Yabe River reach}

Site ' $F$ ' on the left-hand side with riparian trees at 'Funagoya'district in the middle Yabe River reach was chosen as a study site (Figure 14). During the 2012 flood, the riparian trees trapped woody debris pieces and formed woody debris jams. Two types of woody debris jams were distinguished at this study site; one is a woody debris jam trapped by a single tree, and the other is by two or more different trees (Figure 16).

\section{'Nayoshi' and 'Takamine' districts in the middle Nayoshi River reach}

Sites 'G', 'H,' and 'I' on the right-hand side field were selected as study sites (Figures 14). A significant amount of woody debris was trapped by bridges without piers and also deposited on the right-hand side field in the middle Nayoshi River reach (Figure 17).

\section{Individual woody debris pieces}

The direct measurement with a tape measure at 'Ono' and 'Nayoshi' districts were made for woody debris pieces larger than $1.0 \mathrm{~m}$ and $2.0 \mathrm{~min}$ length, respectively

The result of the piece length is shown in Table 2. Here river width at the studied sites is also described for their comparison.'Ikenoyama' and 'Hanzawa' districts produced woody debris pieces while 'Ono', 'Yamauchi', and 'Nayoshi' districts deposited woody debris pieces.

Figure 18 presents the individual pieces in a production site and a deposition site in the same river basin. The length of the pieces and river width were measured by using aerial photos. Therefore we can compare the statistical characteristics (length and diameter) of pieces at the deposition and production sites within the same river basin. For example, the ratio $\mathrm{L}_{1} / \mathrm{L}_{2}=1.7, \quad\left(\mathrm{~L}_{1}+\mathrm{L}_{3}\right) / 2 / \mathrm{L}_{4}=3.1, a_{1} /$ $\alpha_{2}=0.74$ and $\left(\alpha_{1}+\alpha_{3}\right) / 2 / \alpha_{4}=0.77$ can be determined. Here $L_{i}=$ mean length of the piece $i$ and $\alpha_{i}=$ variation coefficient of piece $i$. We can find that pieces at the production sites are around two times longer than those at the deposition sites. However, the variation coefficient of piece length at the production sites is smaller than that at the deposition site. The result on piece diameter is shown in Table 3. We find mean piece diameter $\mathrm{D}_{2}=\mathrm{D}_{5}=0.2 \mathrm{~m}$, and variation coefficient of piece diameter $\alpha_{2}=a_{5}=0.4$.

Figures 19 and 20 show the relationship between the length and diameter of each woody debris piece. Less correlation between length and diameter of each piece was 

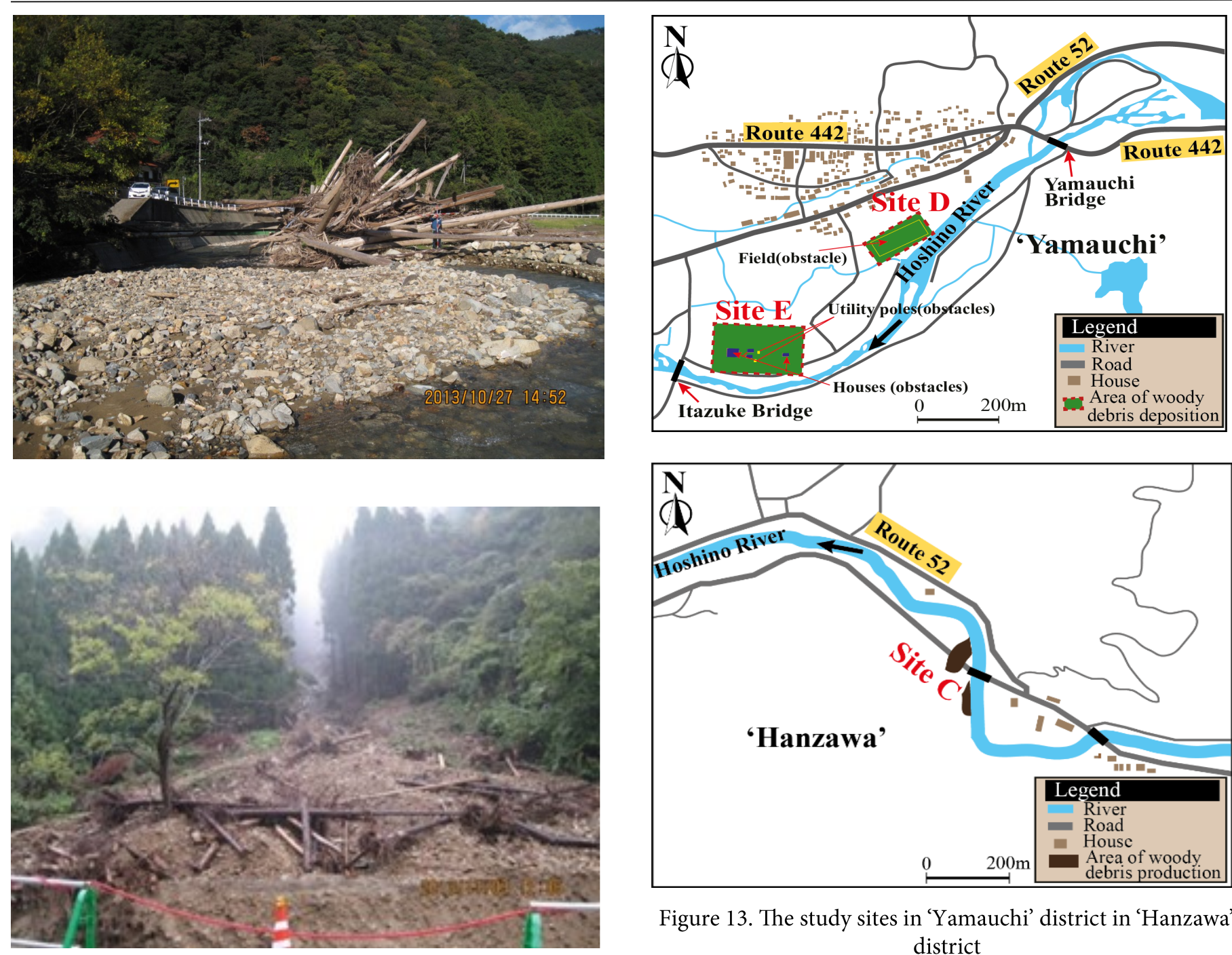

Figure 13. The study sites in 'Yamauchi' district in 'Hanzawa' district

Figure 11. (a) Landslide-induced debris flow in the upstream Nayoshi River reach and (b)woody debris jam at a small bridge in the middle Nayoshi River reach
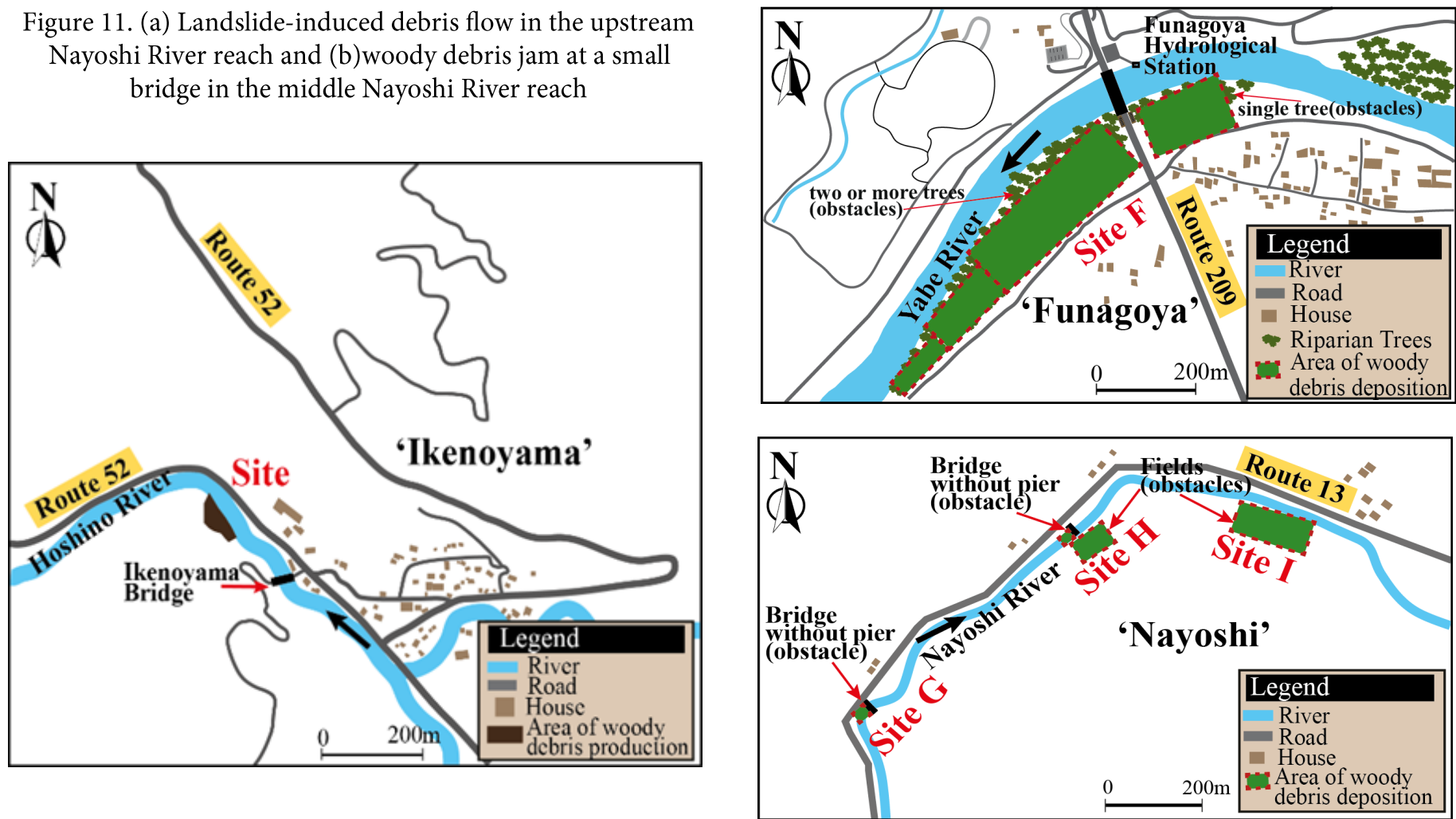

Figure 12. The study sites in 'Ono' district and in 'Ikenoyama' district

Figure 14. The study sites in 'Funagoya' district, 'Nayoshi' and 'Takamine' districts 

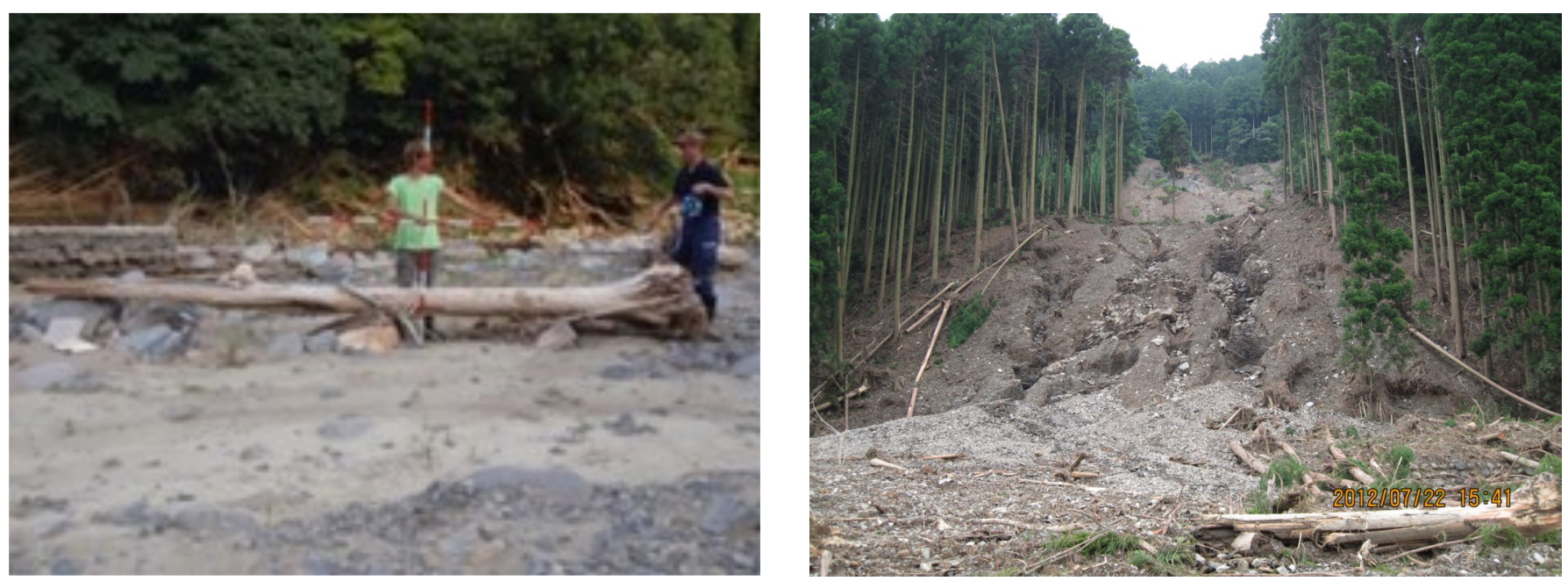

Figure 15. A woody debris piece deposited on the floodplain at 'Ono' district and woody debris produced by Landslide at 'Hanzawa' district.
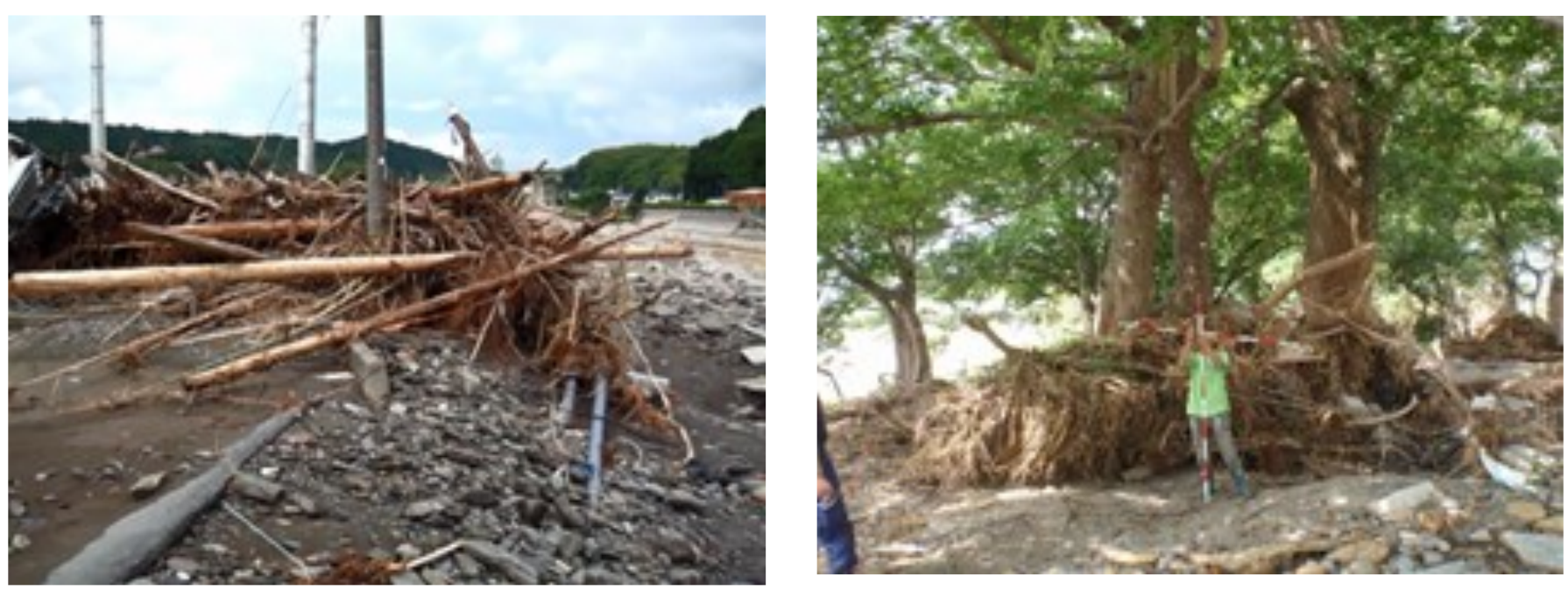

Figure 16. A woody debris jam at utility poles at 'Yamauchi' district and A woody debris jam at three different trees at 'Funagoya' district
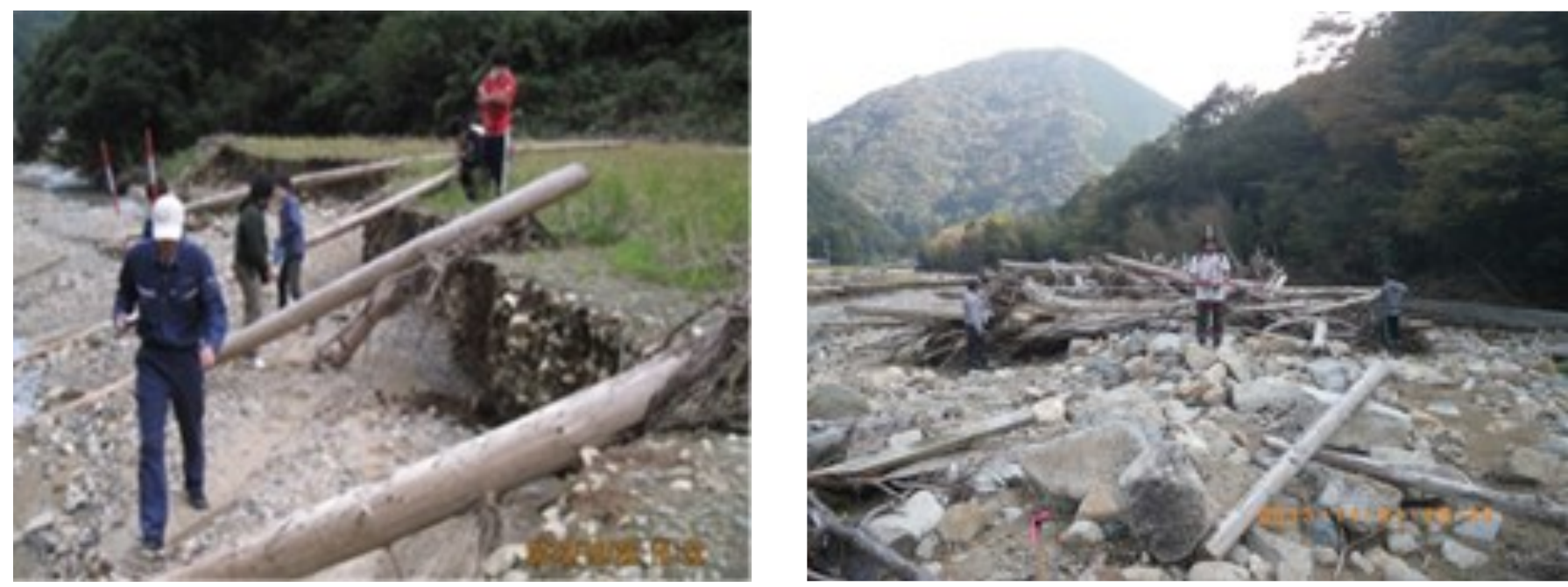

Figure 17. Individual woody debris pieces deposited on the right-hand side field at 'Nayoshi' district, and a woody debris jam formed on the right-hand side field at 'Nayoshi' district. 

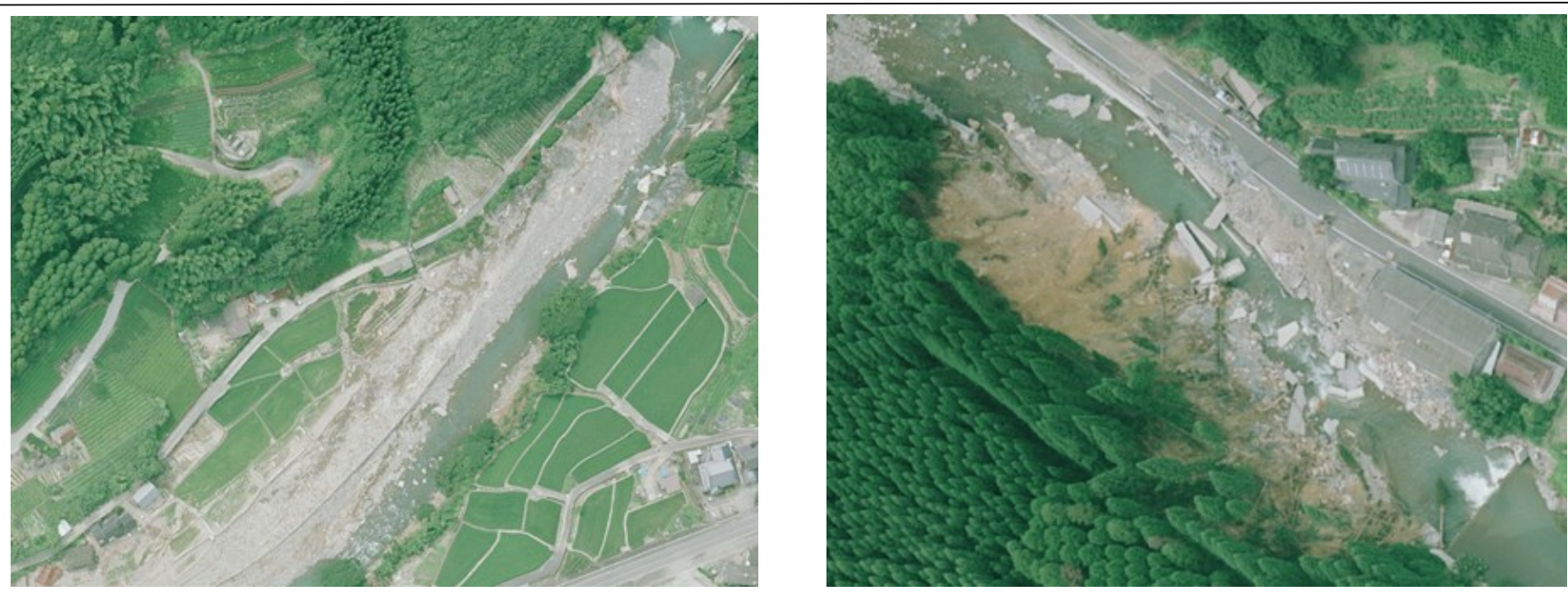

Figure 18. Areal photos show woody debris pieces in 'Ikenoyama' district as a production site and 'Ono' district as a deposition site.
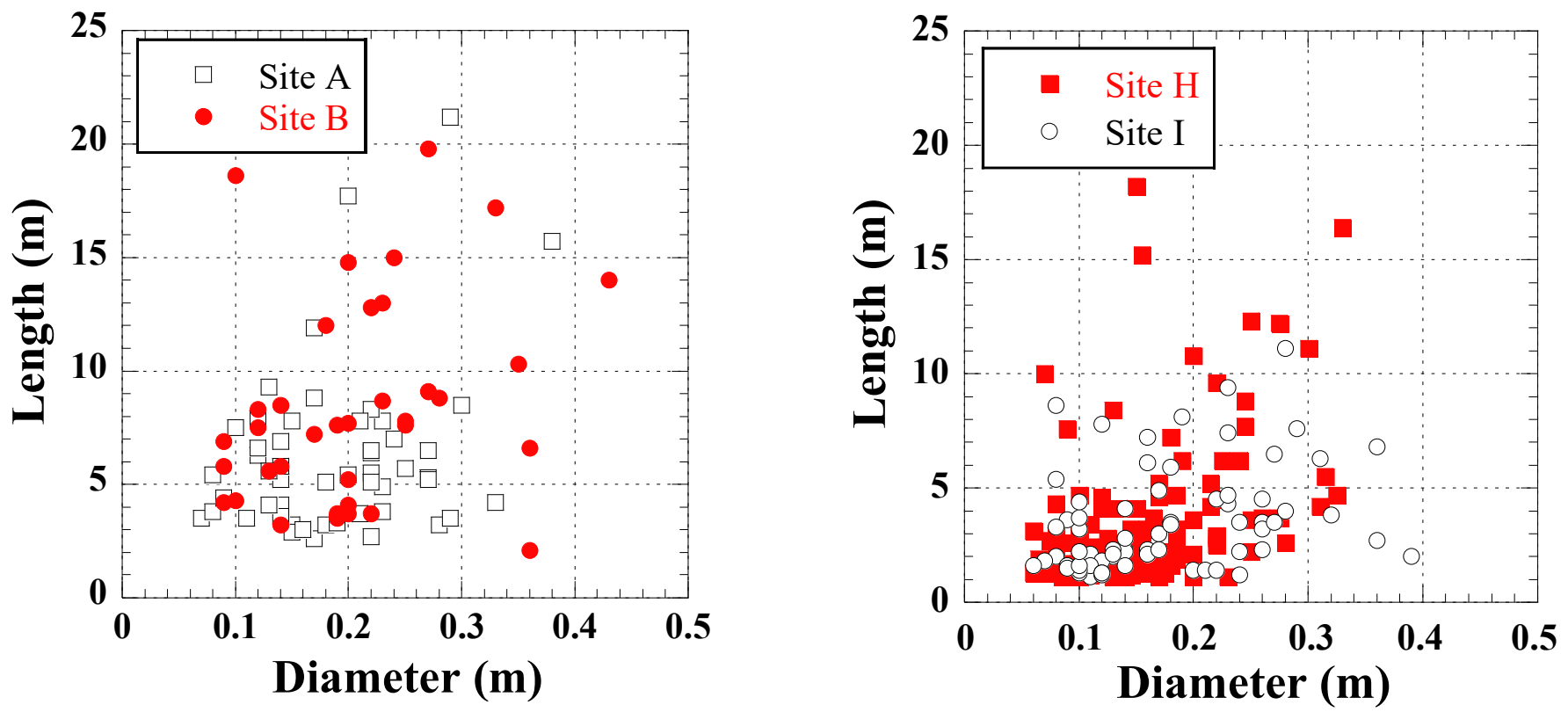

Figure 19. Relationship between length and diameter of each woody debris piece deposited on the floodplain at'Ono' district and on the field at 'Nayoshi' district

found. Therefore characteristics of piece length and diameter can be discussed independently. The statistical characteristics of individual woody debris pieces at the studied sites are examined concerning their length and diameter

Figures 22 and 23 present frequency distribution and cumulative curve of individual woody debris pieces regarding their length and diameter, respectively

\section{The jams of woody debris}

The Yabe and Hoshino River reaches produced a large number of woody debris jams on the flood areas. There were 96 woody debris jams examined at the three districts; 'Ono' district had 1 jam, 'Yamauchi' district had 16 jams, and 'Funagoya' district had 79 jams. The 79 jams have consisted of 63 jams formed by a single standing tree and a utility pole and 16 jams formed by two or more different standing trees

The Tsuwano and Nayoshi River reaches also yielded a large number of woody debris jams. There were 21 woody debris jams examined at 'Nayoshi' district. It had 19 jams on the right-hand side field and 2 jams at the two bridges without a pier

Many of these jams were formed by obstacles to flow, such as riparian trees at 'Ono'district, houses, and utility poles at 'Yamauchi' district, riparian trees, and utility poles at 'Funagoya' district, and bridges at 'Nayoshi' district. However, the other jams were formed on fields without obstacles at 'Yamauchi' and 'Nayoshi' districts. The former indicates the accumulation of woody debris trapped by the obstacles, and the latter expresses the accumulation of woody debris trapped by the deposited pieces on the restricted area of fields or its small topographic relief, such as ridges between neighboring rice fields

Therefore we can distinguish two types of woody debris jam formation; one is a type with an obstacle, and the other is a type without an obstacle

The outline of woody debris jams and obstacles is presented in Table 1. For example, houses were $4.7 \mathrm{~m}$ wide on average in 'Yamauchi' district. A utility pole had a 

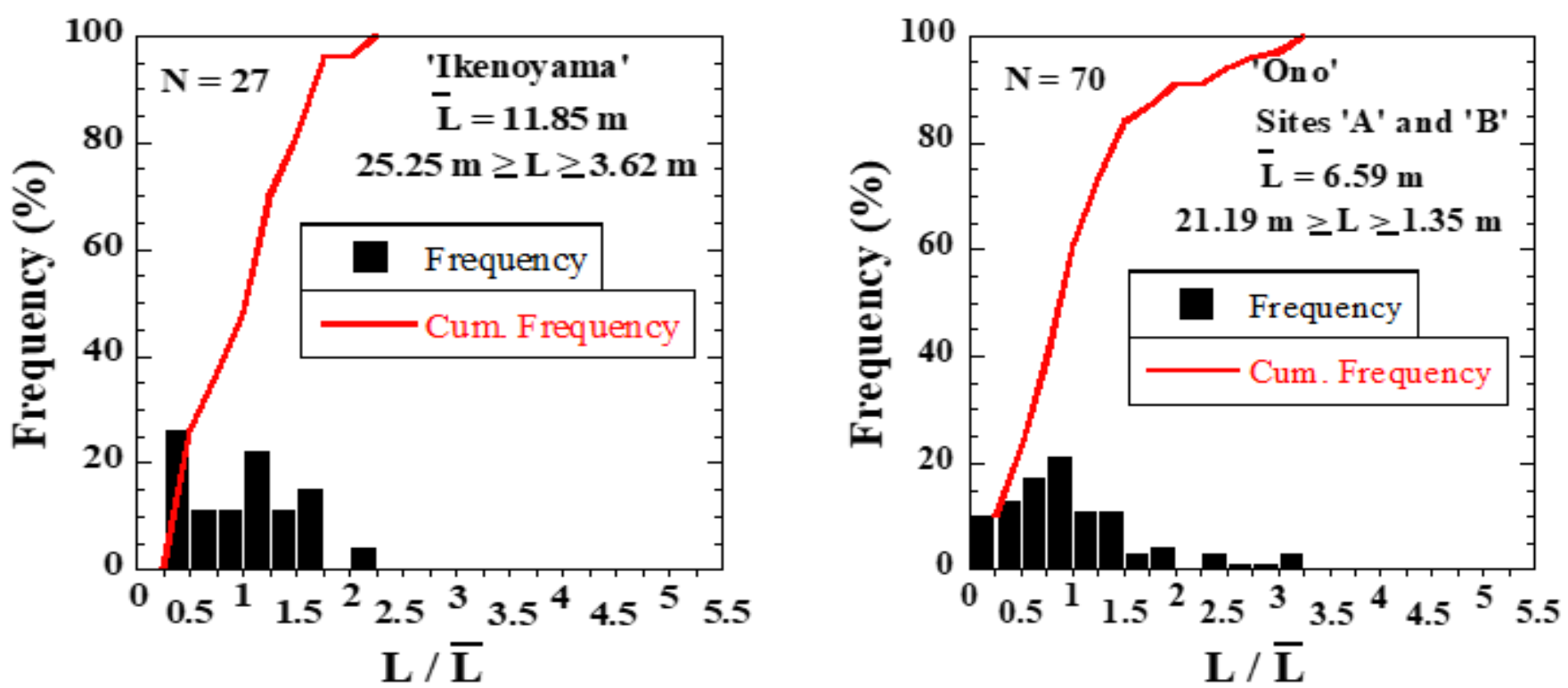

Figure 20. Frequency of length of woody debris pieces at 'Ikenoyama' district and Frequency of individual wood piece's length at 'Ono' district.
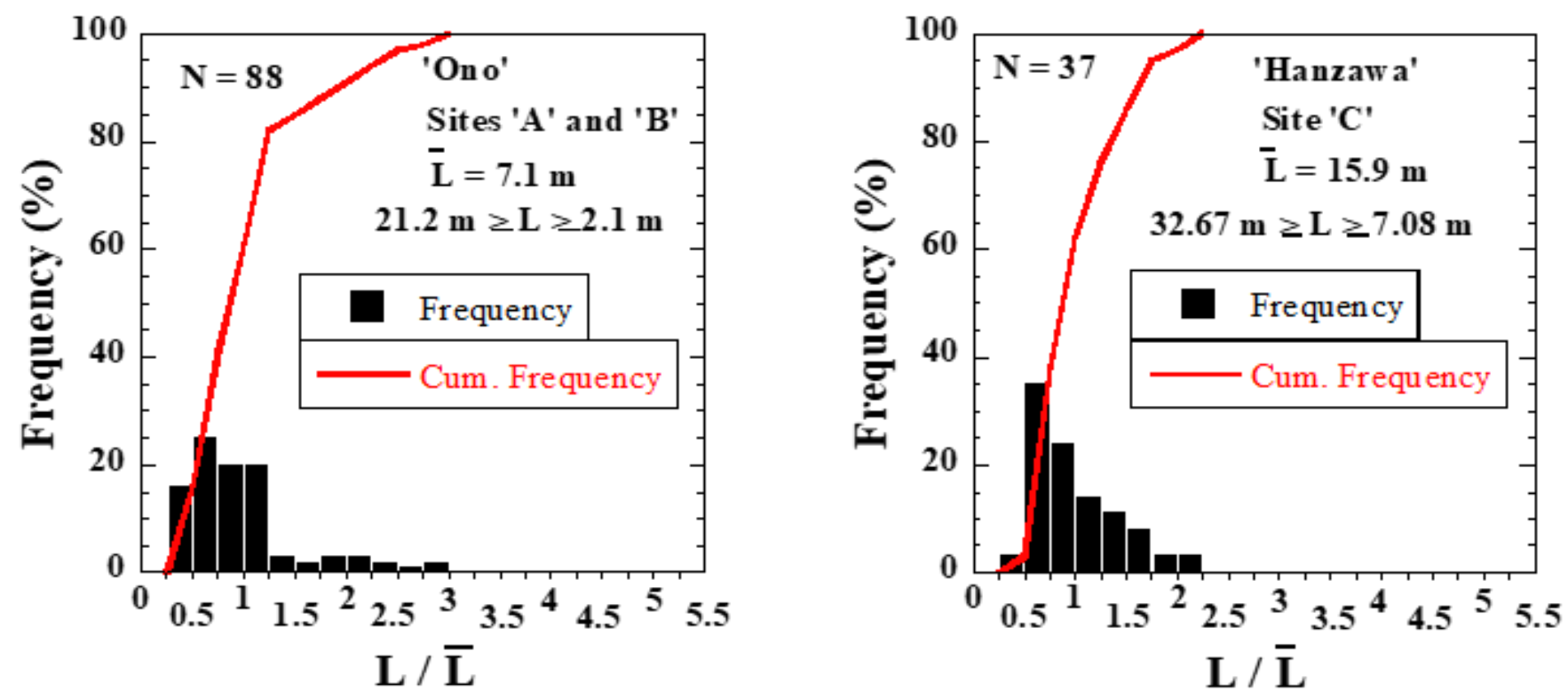

Figure 21. Frequency of individual wood piece's length at 'Ono' district and Frequency of length of woody debris pieces at 'Hanzawa' district.

diameter of about $0.15 \mathrm{~m}$, and a standing tree had a diameter ranging from 0.1 to $1.3 \mathrm{~m}$ at 'Funagoya' district. The upstream and downstream bridges at 'Nayoshi' district had the length of $13.1 \mathrm{~m}$ and $10.75 \mathrm{~m}$, and the thickness of $0.7 \mathrm{~m}$ and $0.8 \mathrm{~m}$, respectively

\section{The scale of jams formed by obstacles}

Figure 24(a) shows the relationship between each woody debris jam's vertical and horizontal scale. In this figure, the horizontal scale of a jam formed by an obstacle is defined as that of a jam in the transverse direction of an obstacle. We discuss factors which determine the horizontal and vertical scale of each woody debris jam formed by an obstacle

The vertical scale of each woody debris jam formed by an obstacle can be determined by flow depth during the flood event. Flow depth was not constant but changed with time during the flood event. Therefore it is implied that the maximum flow depth determines the vertical scale of each woody debris jam formed by an obstacle. Figure 24(b) expresses the relationship between each woody debris jam's horizontal scale formed by an obstacle and that of each obstacle. Figures 25 shows the relationship between each woody debris jam's horizontal scale and the length of the longest piece constituting each jam. Comparing Figures 22 and 23, we find that the horizontal scale of each woody debris jam formed by an obstacle can be determined by the horizontal scale of each obstacle rather than the length of the most extended piece of each jam. 

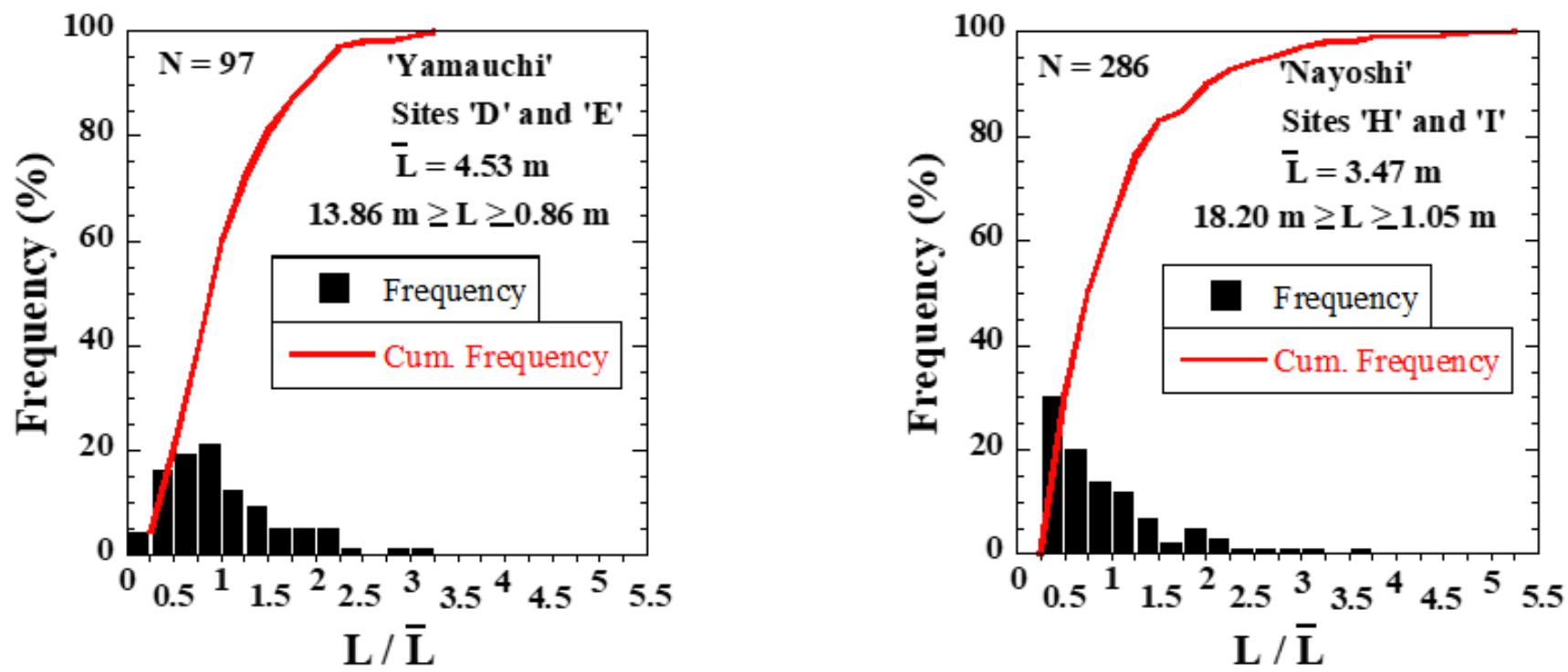

Figure 22. Frequency of individual wood piece's length at 'Yamauchi' district and frequency of length of each wood pieces at 'Nayoshi' district
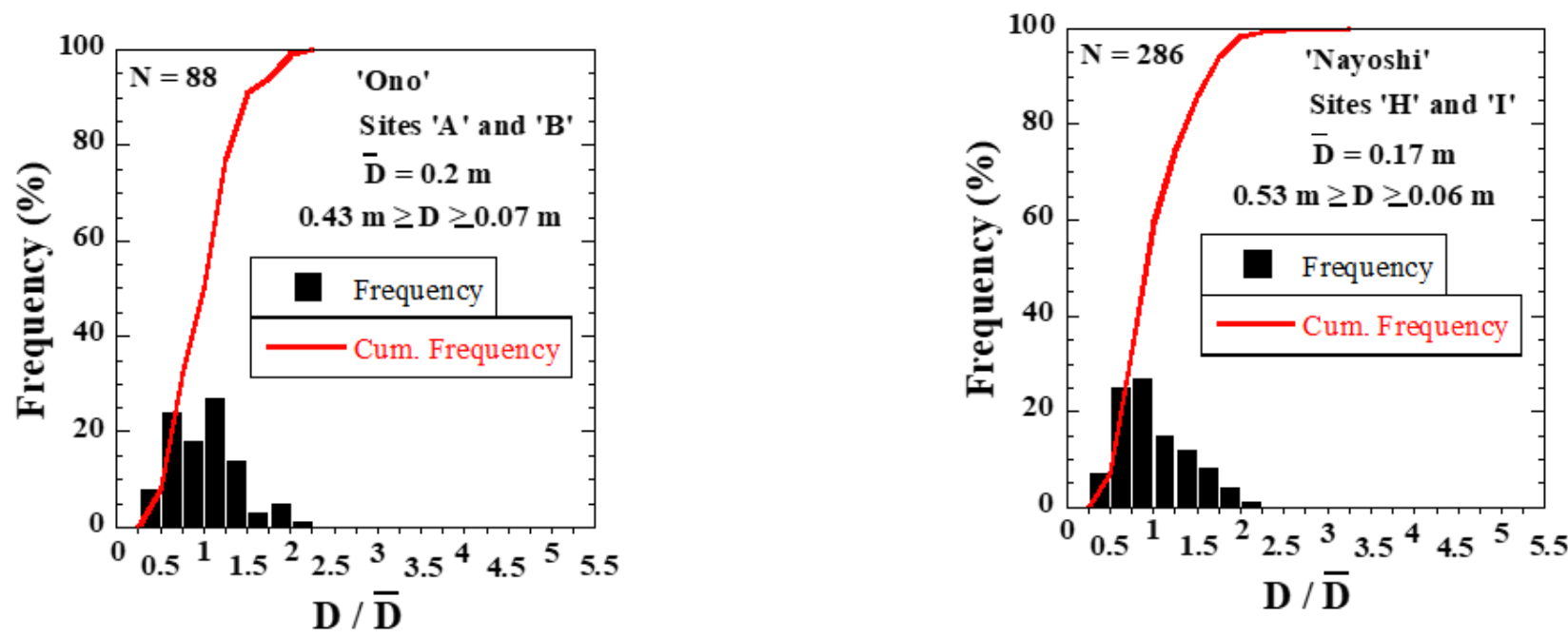

Figure 23. The study sites in 'Funagoya' district, 'Nayoshi' and 'Takamine' districts

Table 1. Outline of woody debris jams and obstacles

\begin{tabular}{|c|c|c|c|c|c|}
\hline Basin & $\mathrm{i}$ & District & $\begin{array}{l}\text { Study } \\
\text { sites }\end{array}$ & Obstacles or fields & Number of jam \\
\hline \multirow{5}{*}{$\begin{array}{l}\text { The Yabe and } \\
\text { River Reaches }\end{array}$} & 2 & 'Ono' & A & Two or more trees & 1 \\
\hline & 4 & 'Yamauchi' & $\mathrm{D}, \mathrm{E}$ & Field & 9 \\
\hline & & & & Houses and utility poles & 7 \\
\hline & 5 & 'Funagoya' & $\mathrm{F}$ & $\begin{array}{r}\text { A single standing trees and utility } \\
\text { poles }\end{array}$ & 63 \\
\hline & & & & Two or more trees & 16 \\
\hline \multirow{5}{*}{$\begin{array}{l}\text { The Tsuwano and Nayoshi } \\
\text { River reaches }\end{array}$} & & & G & & 3 \\
\hline & & Nayoshi & $\mathrm{H}$ & Field & 6 \\
\hline & & & I & & 10 \\
\hline & & & G & Bridge & 1 \\
\hline & & & $\mathrm{H}$ & & 1 \\
\hline
\end{tabular}




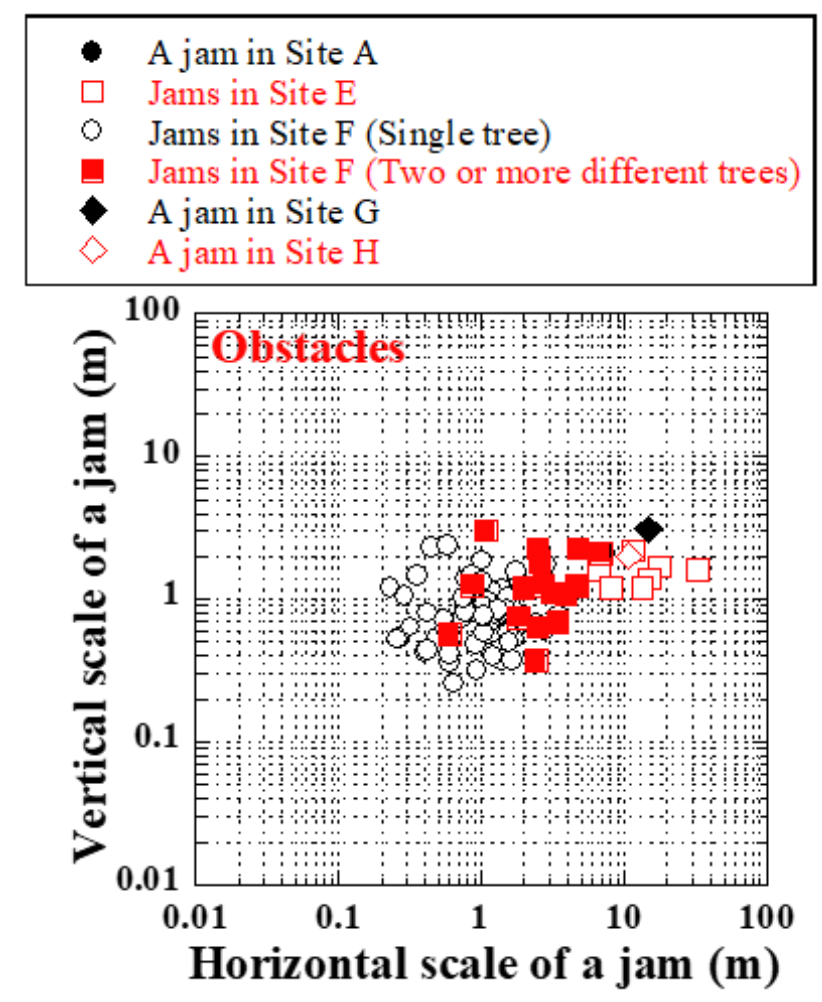

\begin{tabular}{|ll|}
\hline & A jam in Site A \\
$\square$ & Jams in Site E \\
& Jams in Site F (Single tree) \\
& Jams in Site F (Two or more different trees) \\
& A jam in Site G \\
A jam in Site H
\end{tabular}

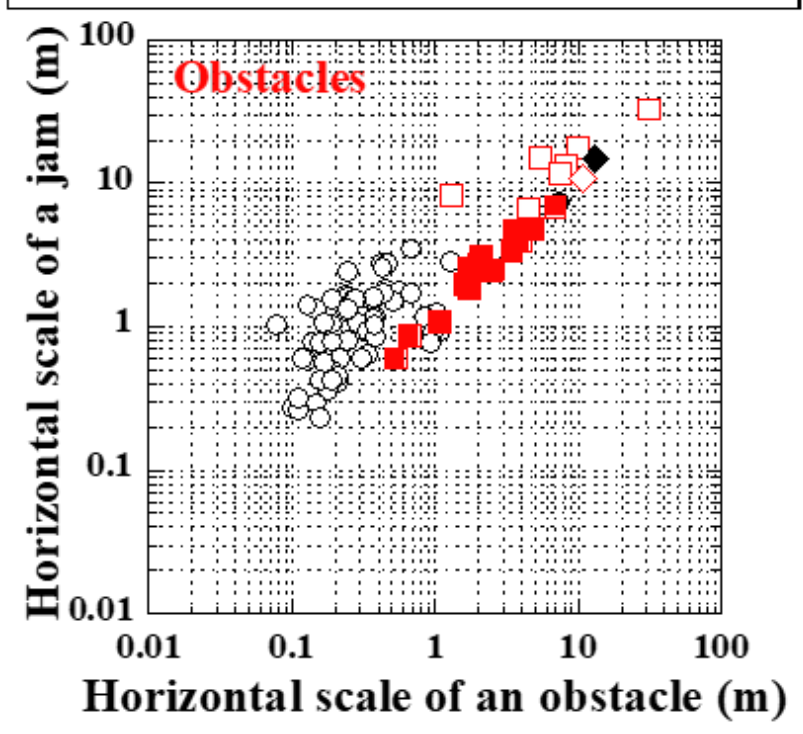

Figure 24. (a) Relationship between the vertical and horizontal scale of each woody debris jam and (b) representative scale of obstacles and scale of woody debris

\begin{tabular}{|ll|}
\hline & Jams in Site F (Single tree) \\
Jams in Site F (Two or more different trees) \\
A jam in Site G \\
A jam in Site H \\
\hline
\end{tabular}

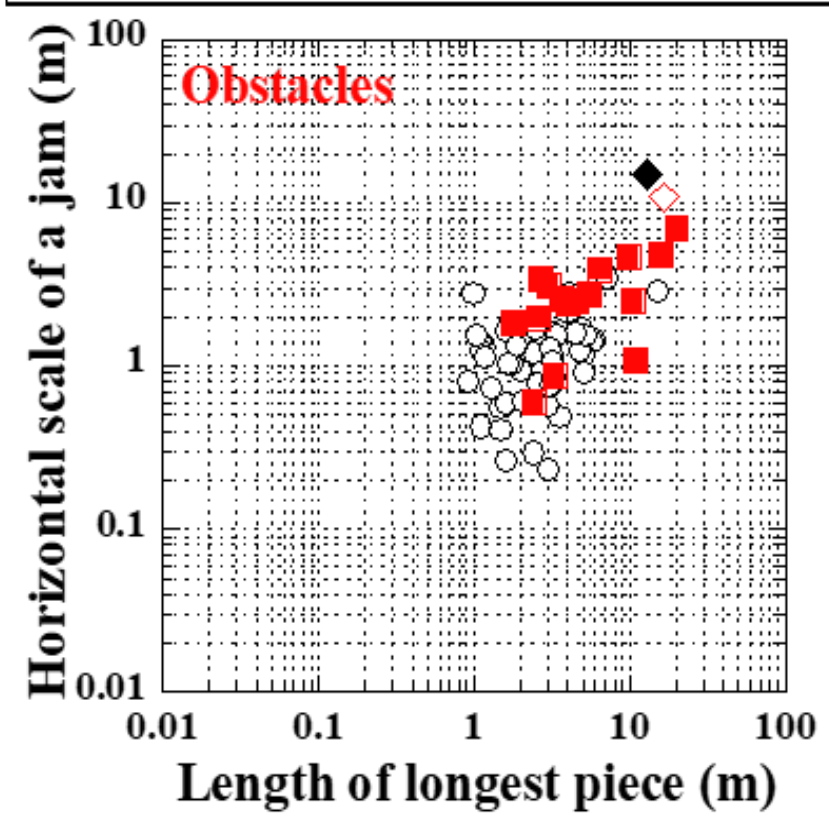

Figure 25. Relationship between length of most extended woody debris pieces and scale of woody debris jams

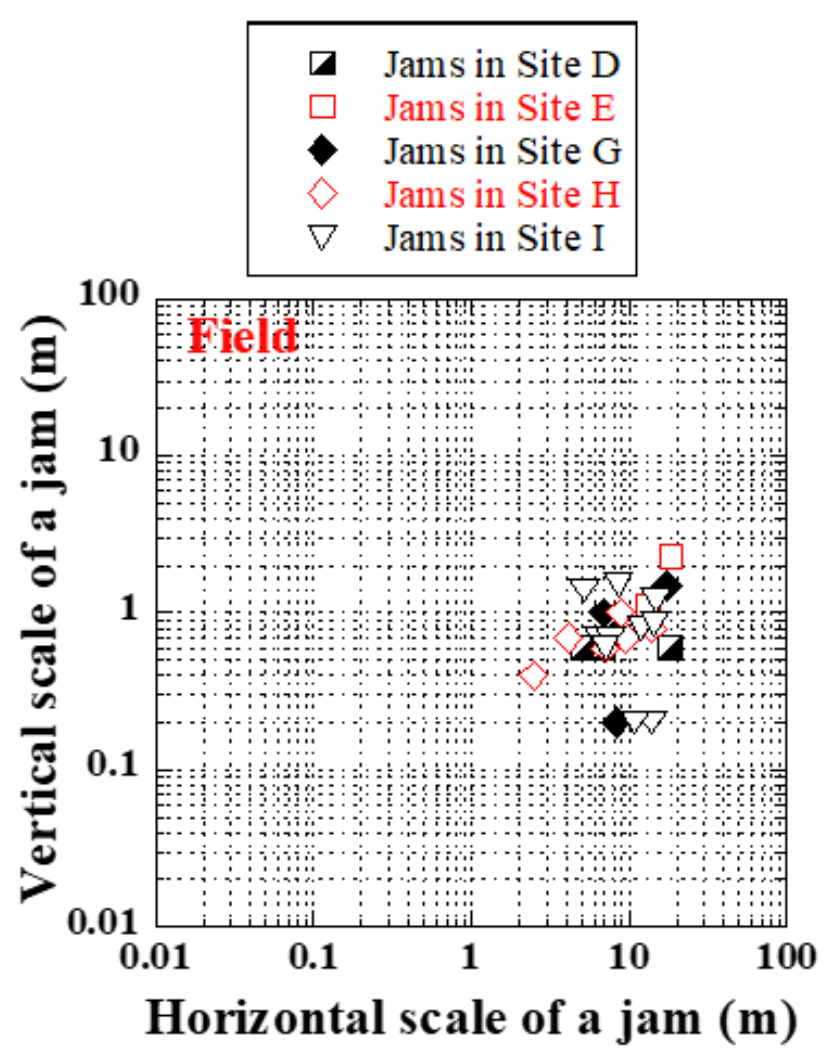

Figure 26. Relationship between verticaland horizontal scale of each woody debris jamformed on fields 
Table 2. Characteristics of the longest piece in each woody debris jam.

\begin{tabular}{|c|c|c|c|c|c|c|}
\hline District & $\begin{array}{c}\text { Studied } \\
\text { site Name }\end{array}$ & Obstacles or Fields & $\begin{array}{c}\text { Number of } \\
\text { the longest } \\
\text { piece }\end{array}$ & $\begin{array}{l}\text { Range of L } \\
\quad(\mathrm{m})\end{array}$ & Mean of L (m) & $\begin{array}{l}\text { Range of D } \\
\text { (m) }\end{array}$ \\
\hline
\end{tabular}

\begin{tabular}{|c|c|c|c|c|c|c|c|}
\hline \multirow[t]{7}{*}{ Funagoya } & $\mathrm{F}$ & $\begin{array}{r}\text { A single tree and } \\
\text { utility pole }\end{array}$ & 52 & $0.92-15.1$ & 3.16 & $0.02-0.22$ & 0.08 \\
\hline & & Two or more trees & 16 & $1.8-20$ & 6.69 & $0.04-1.6$ & 0.36 \\
\hline & G & & 3 & $14.5-18.6$ & 16.17 & $0.18-0.25$ & 0.21 \\
\hline & $\mathrm{H}$ & Fields & 2 & $11.5-17$ & 14.25 & $0.24-0.46$ & 0.35 \\
\hline & I & & 10 & $9.8-16.8$ & 12.14 & $0.22-0.45$ & 0.31 \\
\hline & G & Bridge & 1 & & 13.1 & & 0.19 \\
\hline & $\mathrm{H}$ & & 1 & & 16.7 & & 0.35 \\
\hline
\end{tabular}

Source: field investigations

Table 3. Characteristics of the pieces selected in each woody debris jam at 'Nayoshi' district

\begin{tabular}{|c|c|c|c|c|c|c|c|}
\hline District & $\begin{array}{c}\text { Studied } \\
\text { site names }\end{array}$ & $\begin{array}{l}\text { Obstacles or } \\
\text { fields }\end{array}$ & $\begin{array}{c}\text { Number of } \\
\text { jams }\end{array}$ & $\begin{array}{l}\text { Number of all } \\
\text { the pieces }\end{array}$ & $\begin{array}{l}\text { Number of the } \\
\text { pieces selected }\end{array}$ & $\begin{array}{l}\text { Mean length } \\
(\mathrm{m})\end{array}$ & $\begin{array}{c}\text { Mean } \\
\text { diameter } \\
(\mathrm{m})\end{array}$ \\
\hline \multirow[t]{5}{*}{ Nayoshi } & G & Field & 3 & $34-53$ & $5-13$ & $5.5-7.3$ & $0.18-0.2$ \\
\hline & $\mathrm{H}$ & & 2 & $39-90$ & $5-7$ & $7.6-8.2$ & $0.23-0.29$ \\
\hline & I & & 8 & $20-102$ & $3-13$ & $4.2-8.9$ & $0.17-0.26$ \\
\hline & G & Bridge & 1 & & 9 & 7.6 & 0.23 \\
\hline & $\mathrm{H}$ & & 1 & & 5 & 10.4 & 0.27 \\
\hline
\end{tabular}

Source: field investigations

The scale of jams on the fields without obstacles

Figure 26 shows the relationship between vertical and horizontal scales of each woody debris jam. In this figure, the horizontal scale of a jam on the fields is determined by assuming the plan view of a jam a circular form with the same area as that of the plan view. We discuss factors that determine each woody debris jam's horizontal and vertical scale formed on the field without an obstacle. Figure 27 expresses the relationship between the vertical scale of each woody debris jam on the field and the diameter of the longest piece.

\section{Volume of jams}

Figure 28 shows the relationship between the length and diameter of the selected pieces in each jam. Comparing these values with those in Figure 17 shows the same range of values in these figures. They were assuming that the mean length and diameter of the selected pieces as their representative values in each jam, the volume of the representative pieces can be obtained. Using the total number of pieces and the volume of the representative piece in each jam, a woody debris jam's net volume can be estimated. Figure 29 shows the relationship between the net and apparent volume of a woody debris jam. Their volume ratio $C^{\star}$ is around 0.2 on average

\section{Result and Discussion}

Field surveys were carried in order to explore the characteristics of woody debris production and deposition in the Yabe River basin and the Tsuwano River basin during the 2012 and 2013 floods. Woody debris conveyed by the floods was to be deposited on the riverside slope or flood plain and 

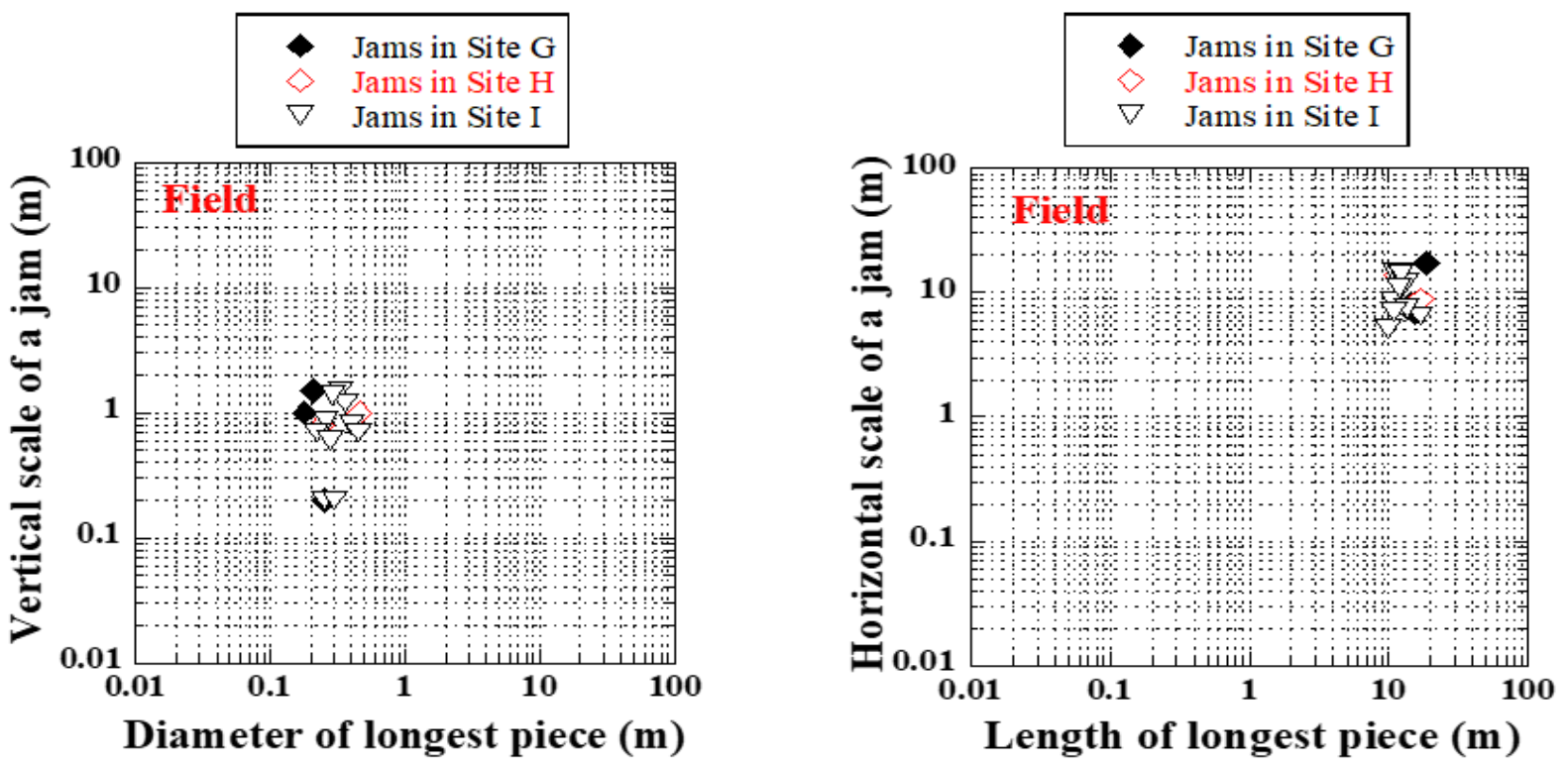

Figure 27. Relationship between (a) vertical scale of a jam and diameter of the longest piece (b) length of longest woody debris pieces and horizontal scale of woody debris jams.

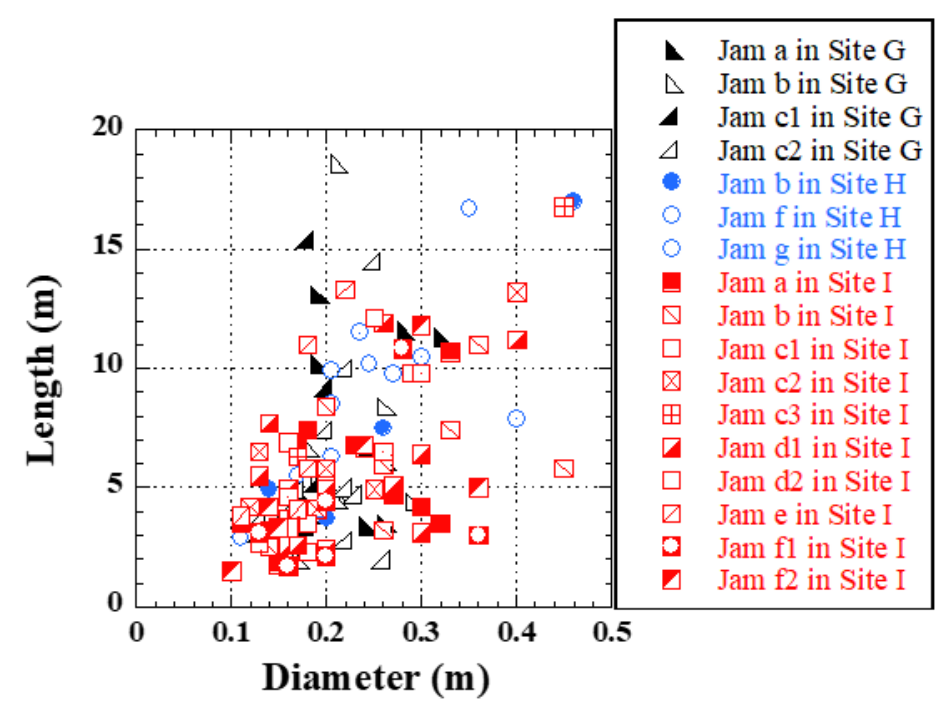

Figure 28. Relationship between length and diameter of the pieces selected in each jam at 'Nayoshi' district (jam a and g indicate the jam at the bridges).

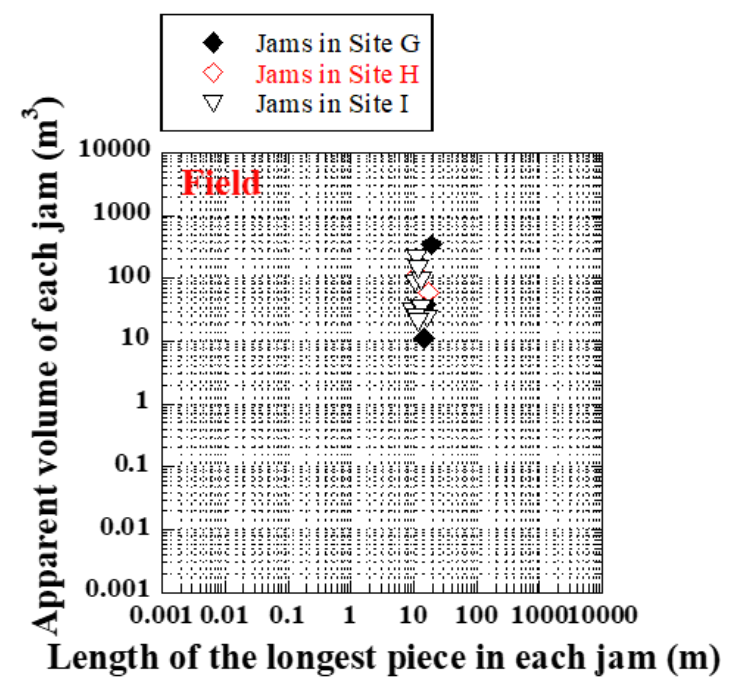

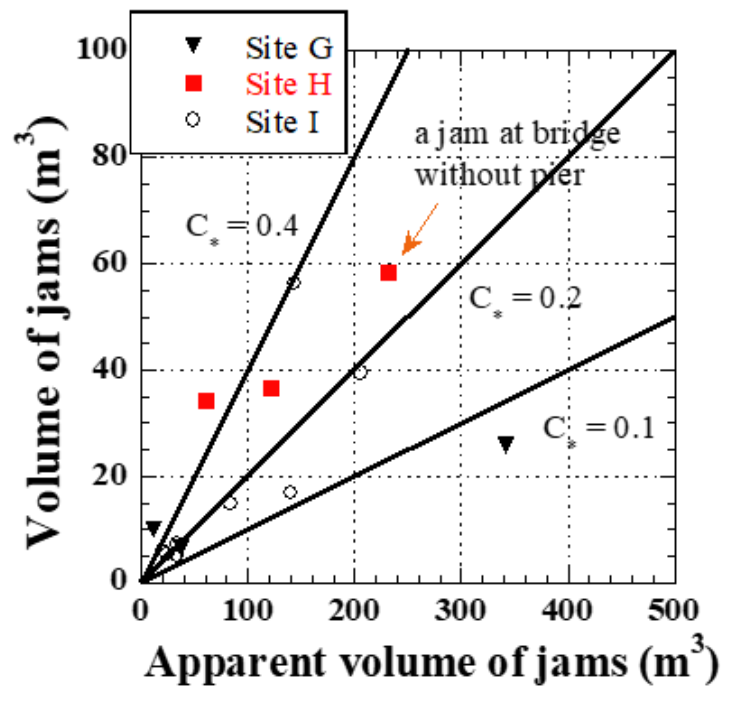

Figure 29.Relationship between the apparent and net volume of jams at 'Nayoshi' district

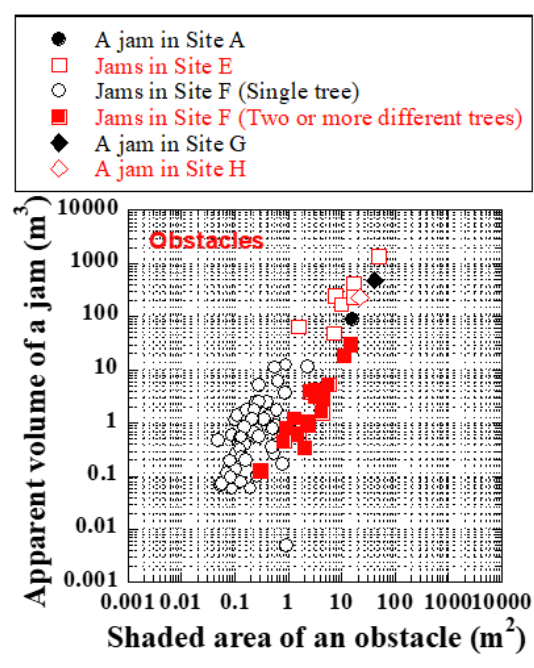

Figure 30. Relationship between (a) volume of woody debris jams and the longest piece (b) volume of woody debris jams and shaded area of obstacles. 
where the woody debris hits an obstacle. Our field surveys show that there are two types of situation of woody debris at the production site and deposition site; one is the rest of individual wood pieces on the riverside slope or floodplain, and the other is the formation of a woody debris jam. Thus, the woody debris jam was distinguished into two types: (1) woody debris with an obstacle and (2) woody debris without an obstacle.

Bridges, riparian trees, utility poles, and houses are the most permanent obstacles to continued downstream transport of woody debris during the floods. The woody debris at the obstacles produces its accumulations or jams. The first deposited pieces on the restricted area of fields or small topographic relief, such as ridges between neighboring rice fields, trapped much woody debris and formed jams in the field. Diehl (1997) explains woody debris in which its length exceeds the sufficient width of openings between the bridge's piers can be blocked by the obstacles and formed a jam. Curran (2010) also reports the river bend served as the depositional site of the formation of woody debris jams in the field. The situation of woody debris in our field surveys provides further evidence for the formation of woody debris jams.

Our field surveys also present that the length of individual woody debris pieces in the production site was two times longer than that of pieces in the deposition site. The phenomenon occurred because the length of individual wood pieces in the production site was longer than river width, and the woody debris contacted with the river bank and river bed during flood conveyed the debris to the deposition site. The decrease in the length of individual woody debris pieces in deposition site seems to be consistent with the previous studies that reported the length of large woody debris decreases with increasing travel distance (e.g., Bochiola et al., 2008; Braudrick et al., 1997)

Here, the longest piece in the jam and the horizontal scale of obstacles in each site influence jam's horizontal scale. The longest piece in a jam was wider than the jam's horizontal scale formed by a single tree. However, Diehl (1997) showed that the longest pieces in single-pier jam observed at three sites along the White River of Indiana was smaller than the horizontal scale of jam. Additionally, the longest piece in a jam in the field influences the apparent volume of the jam (Figure 28a). The piece seems to become a 'key member'. The key member is generally the largest stable piece that can form woody debris jams (Abbe \& Montgomery, 2003).

In summary, the most interesting result to emerge from this study is that there was a significant positive relationship between the shaded area of an obstacle and the apparent volume of woody debris jams (Figure 30b). The relationship offers an empirical equation, as follows.

$$
V_{w d}=C A_{o}^{\alpha}
$$

\section{Where $C=2.5$ and $\alpha=3 / 2$.}

It is difficult to obtain information on the volume of woody debris jams at an obstacle in the field during the flood event. The equation can help to estimate the apparent volume of woody debris jam at obstacles

\section{Conclusion}

The situation of woody debris production and deposition in the Yabe River basin and the Tsuwano River basin during the 2012 and 2013 floods were investigated. The rest of the individual woody debris pieces on the riverside slope or floodplain and the formation of a woody debris jam at obstacles were found. The length of individual woody debris pieces plays an important part in the behavior of woody debris during flood events. In fact, the individual woody debris pieces at the production sites are longer than those at the deposition sites. However, the variation coefficient of piece length at the production sites is smaller than that at the deposition sites.

The longest pieces and horizontal scale of obstacle had identified and appear to be a significant influence on woody debris jam formation. In addition, an empirical equation for predicting the volume of woody debris jams at obstruction was proposed.

Finally, it is plausible that several limitations might influence our results. First, the relationship between the woody debris deposition on the floodplain and hydraulic quantities has not been discussed because of less information on river geometry. Second, the diameter of woody debris pieces delivered by landslides to the river has not been shown due to less information on woody debris in production sites. Therefore, this study is based on limited field data, indicating that extensive investigating is still needed for a complete understanding of the behavior of woody debris during the flood event. It would be interesting to perform an experimental study on the behavior of woody debris jam from the viewpoint of hydraulics

\section{Acknowledgment}

Grants-in-Aid gave support for Scientific Research (25350508) of JSPS, who funded the study in its initial stage. We would like to appreciate their grant-in-aid in this study. We are immensely grateful to Kensuke Sakada for his technical assistance in this study. Also, the first author would like to thank Kyushu University for the post-doctoral fellowship grant in 2016.

\section{References}

Abbe, T.B. and Montgomery, D.R., (2003). Pattern and processes of wood debris accumulation in the Queet river basin, Washington, Geomorphology, 51, 81-107.

Benda, L.E, Bigelow P and Worsley, T.M. (2002). Recruitment of wood to streams in old-growth and second-growth redwood forest, northern California, U.S.A. Canadian Journal of Forest Research 32(8),1460-1477

Bocchiola, D., Rulli, M.C., and Rosso, R., 2006. Transport of large woody debris in presence of obstacles, Geomorphology, 76, 166 -178 .

Bocchiola D., Rulli M.C. and Rosso R., (2008). A flume experiment on the formation of wood jams in rivers. Water Resources Research, 44 (2), W02408.

Braudrick, C.A. and Grant, G.E., (2001). Transport and deposition of large woody debris in streams: a flume experiment, Geomorphology, 41, 263-283.

Braudrick C.A., Grant G.E., Ishikawa Y. and Ikeda H., (1997). Dynamics of wood transport in streams: a flume experiment. Earth Surface Processes and Landforms, 22, 669-683.

Curran J.C., (2010). Mobility of large woody debris (LWD) jams in a low gradient channel. Geomorphology 116, 320-329. 
Diehl T.H.,( 1997). Potential drift accumulation at bridges. Washington : U.S. Department of Transportation, Federal Highway Administration, Report FHWA-RD-97-028.

May C.L and Gresswell R.E,(2003). Processes and rates of sediment andwood accumulation in the headwater streams of the Oregon Coast Range, U.S.A. Earth Surface Precesses and Landforms 28 (4).409-424.

Pagliara S. and Carnacina I. (2010). Temporal scour evolution at bridge piers: effect of woody debris roughness and porosity. Journal of Hydraulic Research. 48 (1), 3-13.

Reeves G.H., Burnett K.M. and McGarry E.V. (2003). Sources of large wood in the main stem of a fourth-order watershed in coastal Oregon. Canadian Journal of Forest Research 33 (8), 1363-1370.

Ruiz-Villanueva, V., Wyzga, B., Hajdukiewicz, H., and Stoffel, M. (2015). Exploring large wood retention and deposition in contrasting river morphologies linking numerical modelling and field observations. Earth Surface Processes and Landforms. DOI:10.1002/esp.3832.

Ruiz-Villanueva, V., Bodoque, J.M., Diez-Herrero, A., Blade, E. (2014). Large wood transport as significant influence on flood risk in a mountain village. Nat Hazards, 74 , 967-987.DOI 10.1007/s11069-014-1222-4.
Rusyda, M.I., Hashimoto, H., Ikematsu, S. and Sakada, K., (2013). Characteristic of woody debris deposition during the Yabe River Flood, Japan: nortern Kyushu Flood Disaster in July 2012. In : S. Fukuoka, H. Nakagawa, T. Sumi and H. Zhang, eds. $12^{\text {th }}$ International Symposium on River Sedimentation, 2-5 September 2015 Kyoto. CRC Press: Advances in River Sediment Research, 181.

Rusyda, M.I., Kusukubo M., Maricar, M.F., Ikematsu, S. and Hashimoto, H. (2014). Woody debris accumulation during the flood event in the Nayoshi River, Tsuwano Town, Japan. Proceedings of $19^{\text {th }}$ Congress of the Asia and the Pacific Division of International Assosiation for Hydro-Environment Engineering and Researh, 21-24 September 2014 Hanoi.

Schmocker, L. and Hager, W.H., (2011). Probability of drift blockage at bridge decks. Journal of Hydraulic Engineering, 137 (4), 269-274.

Wallerstein, N.P. (2003). Dynamic model for constriction scour caused by large woody debris. Earth Surface Processes and Landforms, 28, 49-68.

Welber, M., Bertoldi, W., and Tubino, M. (2013).Wood dispersal in braided stream; Result from physical modelling. Water Resources Research, 49, 7388-7400. 